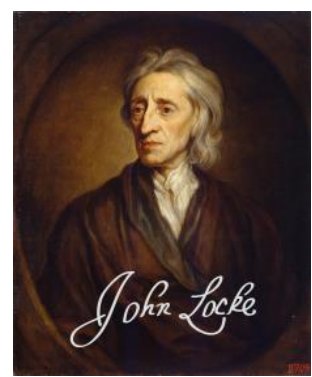

LOCKE STUDIES

Vol. 14

https://doi.org/10.5206/ls.2014.729 | ISSN: 1476-0290

Originally published: 2014

Published online: 19 FEBRUARY 2018

(C) Locke Studies, 2014

\title{
Theologia, Ethics, and Natural Law in Locke's Classifications of Knowledge and Adversaria
}

GIULIANA DI BIASE (GABRIELE D'ANNUNZIO UNIVERSITY OF CHIETI-PESCARA)

Recommended citation:

Di Biase, Giuliana. "Theologia, Ethics and Natural Law in Locke's Classifications of Knowledge and Adversaria." Locke Studies 14 (2014): 177-237. https://doi.org/10.5206/ls.2014.729

For more information about this article:

https://ojs.lib.uwo.ca/index.php/locke/article/view/729

Locke Studies is published by The John Locke Society.

This is an open access article published under the terms of the Creative Commons AttributionNonCommercial-ShareAlike 4.0 International license, which permits use, distribution and reproduction in any medium, provided the original work is properly cited and shared under the original license. 


\title{
THEOLOGIA, ETHICS, AND NATURAL LAW IN LOCKE'S CLASSIFICATIONS OF KNOWLEDGE AND ADVERSARIA
}

\author{
GIULIANA Di BIASE
}

\begin{abstract}
Between 1670 and 1687, Locke wrote some classifications of the branches of knowledge and some adversaria containing guidelines for the writing of commonplace books. Both are to be found in his notebooks and journals. Locke's classifications represent an important source for investigating the role and relevance he attributed to traditional academic disciplines such as Theologia, Metaphysica, and Physica, and, in particular, his manner of conceiving of the object of theology. With reference to the latter, the classifications show important modifications over time: the first schemes (1670-72) are representative of a naturalistic approach to theology, whereas later schemes (1681) are more sensitive to the model introduced by the theological systems of Reformed theologians such as Polanus and Ames, who insisted on the practical dimension of the discipline. 'Ethica sive lex naturae', one of the subheadings of Theologia in Locke's earlier classifications, is absent from those he wrote in 1681, having been substituted by 'Moralia': this substitution seems to be motivated by Locke's intention to emphasize the relevance of the performance of moral duties, the objects of 'Moralia', in Christian life. In a later scheme dating from c.1686-7, Locke remoulds his manner of classifying completely - the outline is similar in some respects to the division of the sciences on the last pages of the Essay concerning Human Understanding. Theologia is subsumed under Physica, whereas Politia and Prudentia, two of the main headings in Locke's earlier classifications, are positioned under a new heading, Practica, inspired by the Aristotelian model. Ethics is located under this heading, before Politia and Prudentia. This ordering might be due to Locke's intention to emphasize the priority of ethics and its basis, natural law, with respect to politics and civil law, a priority which was not clearly represented in his previous schemes. In order to investigate the role and relevance attributed to ethics and natural law in Locke's various classifications, I will focus on each scheme separately; in the conclusion, attention will be drawn to another, later outline of Theologia which Locke composed in 1694, where ethics is once again one of the branches of theology but there is no longer any mention of natural law. Revelation, not natural law, appears to be the basis of ethics in this later scheme.
\end{abstract}

Keywords: John Locke, Ethica, lex naturae, Theologia, lex civilis, Politia, Prudentia. 


\section{Introduction}

Locke shared with his contemporaries a marked interest in systematizing knowledge, an interest apparent in the Baconian project of an Instauratio Magna as well as in the encyclopedic works of Johann Alsted, Johann Comenius, Athanasius Kircher, Gottfried Leibniz, and many others: ${ }^{1}$ the various sintagma, artes universales, digesta sapientiae, claves doctrinarum, theatra or templa mundi which filled the top shelves of seventeenth century monasteries, universities and noble libraries evidenced a persistent attempt to reduce the immense architecture of the world into the format of a scheme or a diagram. For the most part these works are characterized by Ramistic and Baconian features, as well as by the use of Kabbalistic techniques extended to the exegesis of the book of the universe, and combinatory methods akin to those employed by Raymond Lull. They also attest the presence of ideas lying on the border between the serious mathematical study of combinationes and pansophic suggestions, sometimes associated with magical reminiscences. The use of such schemes in encyclopedic works was intended to illustrate the idea of a harmonia mundi, as well as the pansophic ideal of a universal connection between the various sciences. This ideal was common to Descartes and his adversary Comenius, as well as many other seventeenth century philosophers and theologians of different confessions.

In comparison to the encyclopedic model typical of his time, Locke's classifications seem rather crude: he neither made massive use of dichotomic techniques, nor introduced multiple ramifications springing from the various items being classified. Locke simply aligned the names of the different branches of knowledge as headings under which he collected a series of topics, distinguishing between subheadings and correlated items. The

1 As the bibliography on this topic is immense, I refer only to three seminal works: G. H. Turnbull, Hartlib, Dury and Comenius (London, 1968); Charles Webster, The Great Instauration: Science, Medicine, and Reform, 1626-1660 (London, 1975); Tore Frängsmyr (ed.), The Structure of Knowledge: Classifications of Science and Learning since the Renaissance (Berkeley, 2001). 
different disciplines were linked together by very few cross-references formulated through verbal clauses, without employing any mark or symbol. Clarity and simplicity were preferred to complicated structures.

Some of Locke's schemes are named 'Adversaria', others are inserted into notebooks to which he assigned this name. According to Cicero, the practice of writing adversaria - notebooks collecting excerpta and loci communes extrapolated from discourses and orations - had its origins in classical topics and rhetoric and was conceived of as an indispensable aid to memory. This practice developed enormously during the middle ages: the various florilegia, collectanea and digesta written in this period were the outcome of a process of elaborating extracts directed to ordering knowledge. With the invention of the press, manuals on the art of memory, florilegia and encyclopedic summae became more numerous, yet the aim was not merely that of ordering knowledge but also of devising methods for archiving information. Sixteenth and seventeenth century authors such as Cardanus, Gessner, Alsted, Keckermann, Jungius, Sidelius, Schubart and Locke himself showed a persistent interest in the practice of cataloguing intended as a combinatory art distinct from its medieval ancestor, being structured independently of any topical or metaphysical principle of ordering. Knowledge was homogenized into alphabetically or numerically ordered entries; ${ }^{2}$ the first was the method of common-placing devised by Locke in his article published in Jean Le Clerc's Bibliothèque Universelle. ${ }^{3}$ Here, the

Cf. Jean-Marc Chatelaine, 'Les recueils d'Adversaria aux XVI $\mathrm{I}^{\mathrm{e}}$ et $\mathrm{XVII}{ }^{\mathrm{e}}$ siècles: des pratiques de la lecture savante au style de l'érudition', in Frédéric Barbier et al (eds.), Le livre et l'Historien: Etudes offertes en l'honneur du Professeur Henry-Jean Martin (Geneva, 1997), 169-86. Locke's interest in cataloguing is also attested by the pigeon-hole cabinet he devised for the storage of rolled papers in 1680: see Locke to Nicolas Toinard, Dec. 13, 1680, in E. S. de Beer (ed.), The Correspondence of John Locke, (8 vols., Oxford, 1976-), ii, 315-22.

3

Cf. John Locke, 'A New Method of a Common-Place-Book, Translated Out of the French from the Second Volume of the Bibliothèque Universelle', in The Works of John Locke (9 vols., London, 1824), ii, 441-59. 
notebook was no longer conceived as a deposit for rhetorical tools but as an instrument based on the conventional rules of archiving, independent from criteria relating to content. Rather than being an aid to memory, the notebook represented a substitute for it.

As his many notebooks and journals show, Locke was a meticulous and assiduous common-placer, who filled volume after volume with arguments on the most disparate matters; he might have felt the need to establish a superior ordering among the many subjects which attracted his curiosity, a hierarchy among the various subjects based on criteria relating to their content and importance in human life. This need is expressed by Locke's classifications. The intellectual world he lived in, but also his private world, claimed a hierarchical ordering capable of expressing clear priorities and of highlighting the most important concerns in human life, its sense and supreme end.

Locke wrote his classifications and some adversaria containing guidelines for the writing of commonplace books between 1670 and 1687 . These schemes are to be found in manuscripts belonging to the Bodleian Library. ${ }^{4}$ Locke never published any of these outlines: the division of the sciences at the very end of the Essay concerning Human Understanding ${ }^{5}$ represents a somewhat simplified version of the more detailed classifications he had previously written. The way of classifying is also different in the Essay, both in the order and in the number of disciplines involved. Locke might have been dissatisfied with his previous classifications, for a number of reasons which I shall attempt to illustrate, at least in part, in what follows.

4 See 'Adversaria 1661', MS Film 77, ff. 1-2, undated; 'Sapientia', MS Locke c. 28, f. 41, dated 1672; MS Locke f. 15, pp. 110, 119-20, 122-23, undated; MS Locke c. 28, f. 51, dated 1677; MS Locke f. 2, pp. 247-52, dated 1677; MS Locke c. 42, p. 22, dated 1679; 'Adversaria 1661', p. 25, undated; 'Adversaria 1661' back endpaper, undated; 'Adversaria 1661', pp. 290-1, dated 1681; MS Locke c. 28, ff. 157-58, undated; MS Locke c. 28, ff. 155-56, undated.

5 John Locke, An Essay concerning Human Understanding, ed. P. H. Nidditch (Oxford, 1975), IV. xxi. 1-5, 720-21. 
The structure of Locke's adversaria (all probably written in 1677 ) is based on the model of faculty psychology, whereas his classifications introduce a list of disciplines hierarchically ordered (the order varies over time, especially with reference to theology). Broadly speaking, the framework of the first schemes ('Adversaria 1661 ', ff. $1-2$, and 'Sapientia $\left.72^{\prime}\right)^{6}$ appears to be shaped into the scholastic model, which opposed theoretical to practical disciplines. In two subsequent outlines ('Adversaria 1661', pp. 290-91 and MS Locke c. 28, ff. 157-58, both probably written in 1681), ${ }^{7}$ Locke introduced some important modifications, especially with reference to the greater number of disciplines involved; in a later scheme (MS Locke c. 28, ff. 155-6, dating from ca. 1686-7), ${ }^{8}$ Locke remoulded his manner of classifying by introducing several innovations including the use of a new heading, Practica: under this he subsumed both Politia and Prudentia, two of the main headings in his previous classifications, postponing both to 'Ethica' which, in the earlier schemes, was one of the subheadings of Theologia. This order might be due to Locke's intention to emphasize the priority of natural law, understood as the basis of ethics, over civil law, a priority he also insisted on in his second Treatise of Government. In the division of the sciences at the end of the Essay, modelled on the scheme in MS Locke c. 28, ff. 155-56, ethics is the only discipline mentioned under Practica, described as 'the most considerable'.

6 With reference to the dating of the first outline, see J. R. Milton, 'The Dating of “Adversaria 1661"”, The Locke Newsletter 29 (1998): 105-17. According to Milton, the table was written around 1670.

7 The two outlines are almost identical. The second seems to be a fair copy of the first, which is dated 1681. A description and transcription of the second outline are to be found in Paul Schuurman, The Digital Locke Project (Amsterdam: Digital Production Centre of the University Library of the University of Amsterdam, 2006), available from: http://www.libraries.psu.edu/tas/locke/ index.html\#jca [cited 20 January 2014].

8 Taking into account similarities in the size of sheets, layout, and content, Schuurman argues that this paper is a continuation of ff. 145-52 of MS. Locke c. 28, containing the essay 'Of Ethick in General', and probably also dates from ca. 1686-7. See Schuurman, Digital Locke project. Text descriptions [cited 20 January 2014]. 
In order to highlight the priority of ethics and natural law with respect to politics and civil law, Locke may have felt it necessary to remove the first from the outline of Theologia. This move implied a departure both from the Thomistic model of natural theology including the exposition of natural law (a model to which Locke's first schemes conformed), and from the model introduced by some Reformed theological systems, which emphasized the practical dimension of the discipline.

In a later outline of theology ('Adversaria Theologica 94', ff. 17), Locke once again included ethics under this heading, characterizing its object in terms of duties. This definition was in harmony with the educational project formulated in Some Thoughts Concerning Education, which made respecting ones duties (especially civil duties) the axis of a gentleman's ethics. There was no longer any mention of natural law in this later outline: the foundation of ethics seemed now to lie in revelation, not in the norms of the law of nature. The absence of natural law might have been due to the difficulty Locke encountered in attempting to reconcile a natural with a revealed approach to theology. This difficulty was already apparent in his classifications written in 1681, where there was no mention of natural law.

In this article I examine the role and relevance Locke attributed to ethics and natural law in his various classifications, by focusing on each separately. In the conclusion, attention will be drawn to the later outline of Theologia which appears in the first pages of 'Adversaria Theologica', in order to make a comparison with the previous classifications. The various schemes to which I will refer throughout the article are reproduced at the end as appendices.

\section{Scheme 1: 'Adversaria 1661'and 'Sapientia 72'}

In a classification presumably dating to $1670,{ }^{9}$ Locke introduced four disciplines: respectively, Theologia, Politia, Prudentia and Physica sive Corporum scientia. This was the first of the

\footnotetext{
9 Mark Goldie calls this 'Adversaria A' in order to distinguish it from Locke's other classifications. Cf. Locke: Political Essays, ed. Mark Goldie (Cambridge, 1997), 215.
} 
classifications written by Locke; the outline (hereafter Scheme 1) is untitled and in his own hand. ${ }^{10}$ Scheme 1 is inspired by the scholastic tradition: Locke had read Aristotle, Aquinas and Suárez during his first years at Christ Church, as prescribed by the university curriculum. ${ }^{11}$ A number of Thomistic arguments, especially in the first and seventh of Locke's Essays on the Law of Nature, suggest that he had read Aquinas' Summa in the original, though it is sometimes difficult to establish whether Locke was indebted more to Aquinas than to Hooker's Laws or Suárez's Tractatus de Legibus for any of his scholastic notions. Again, passages from Aristotle's Nicomachean Ethics concerning the rational nature of man and the distinction between legal and natural justice appear in the first and third of the Essays. ${ }^{12}$

In positing Theologia in first place Locke was faithful to the scholastic tradition, which elevated this discipline to the role of supreme theoretical science, distinguishing it both from practical sciences (ethics, politics and economy), and poietic or productive sciences (téchnai). As for Politia, in Aristotle's lexicon the term sometimes denoted any form of government, ${ }^{13}$ sometimes one of the most perfect forms (a mixed constitution between oligarchy

10

Locke's original tabular arrangement is reproduced in Two Tracts on Government ed. Philip Abrams (Cambridge, 1967), 246-47; Mark Goldie's more recent transcription of the same outline does not maintain this arrangement. See Locke, Political Essays, 215.

11 Cf. E. G. W. Bill, Education at Christ Church Oxford, 1600-1800 (New York, 1988), 297. The preferred edition of the Nicomachean Ethics was that commented upon by Dionysius Lambinus (De Moribus ad Nichomachum libri X (Basle, 1566)), or the Epitome Doctrinae Moralis written by Theophilus Golius (London, 1662). The most widely used manual on morals was the short treatise by Eustachius a Sancto Paulo, Ethica, sive Summa moralis disciplinae (London, 1652), inspired by Aristotle's scholastic commentators: with regard to natural law, Eustachius explicitly referred to Aquinas's Summa, Ia IIae, q. 91.

12 See the 'Introduction' to John Locke, Essays on the Law of Nature ed. Wolfgang von Leyden (Oxford, 1954), 35-36.

13 Aristotle, Politics, 1279a 38-9. 
and democracy, characterized by the lack of any excessive difference in wealth between the rich and the poor). ${ }^{14}$ Locke's preference for Politia instead of Politica might have been due to his desire to conform to the Aristotelian lexicon, but also to the decline of this latter term, which in the seventeenth century was often used to refer only to the administrative aspect of politics (politics as the art of the state), not to the architectonic one (politics as the supreme legislative science). ${ }^{15}$ In Scheme 1, politics is the Aristotelian-Thomistic science which consists in both fundamentals and administration; in characterizing Politia as both architectonic and deliberative, Locke seems to reject any assimilation of politics to the art of the state. ${ }^{16}$

As for Prudentia, the use of the term to identify the dominion of practical wisdom was not extraordinary in Locke's time. ${ }^{17}$ It had the authority of a long-standing tradition, going back to Aristotle's concept of phrónesis. This same tradition was systematized by scholastic philosophers, mainly by Aquinas. The latter identified

14

Aristotle, Politics, 1289a 36-7.

15

Maurizio Viroli, From Politics to Reason of State: the Acquisition and Transformation of the Language of Politics, 1250-1600 (Cambridge, 1992), 238-80.

16 This rejection was a consistent feature of Locke's political thought: cf. Locke, 'Some Thoughts concerning Reading and Study for a Gentleman', in Some Thoughts concerning Education, ed. John W. Yolton and Jean S. Yolton (Oxford, 1989), 321, where he affirms that 'Politics contains two parts very different the one from the other. The one containing the Original of Societies, and the Rise and Extent of Political power, The Other, the Art of Governing men in Society. The first of these hath been so bandied amongst us for this sixty years backward, that one can hardly miss Books of this kind'. On this first part of politics Locke recommends reading Richard Hooker, Algernon Sidney and his own Two Treatises of Government.

17

In The Art of Logick or the Entire Body of Logick in English (London, 1654), one of the most influential British Aristotelian logicians in Locke's time, Zachary Coke, divided knowledge into Sapientia (the realm of theoretical disciplines inquiring into first causes), and Prudentia (the dominion of practical wisdom). For the meaning of prudence in Locke's classifications, see Giuliana Di Biase, 'The Development of the Concept of Prudentia in Locke's Classifications of Knowledge', Society and Politics, 7 (2013): 85-125. 
prudence with an activity of reason requiring knowledge of the universal principles of reason, in order to deliberate well about what it is better to do in certain circumstances. Aquinas distinguished between eight habits of prudence (memoria, intellectus sive intelligentia, docilitas, solertia sive eustochia, ratio, providentia, circumspectio, cautio). He went on to list some subjective species of prudence (militaris, oeconomica, legispositiva, politica; with reference to theorizing, physica, dialectica, retorica). Finally, he mentioned some potential parts of prudence or closely allied virtues, analogous to those dispositions which Aristotle recognized as proper to the phrónimoi (eubulia, or deliberating well; synésis, or judging well according to common law; gnome, or the wit to judge in matters of exception to general law). ${ }^{18}$ In Scheme 1, Locke follows this pattern: Prudentia is a universal principle (a meta-virtue) which requires both intellectual knowledge of man's supreme ends (that is, a theory of good), and the possession of those moral habits necessary to act in accordance with them. Prudentia is separated from Politia because of its broader content, which goes beyond political prudence; it is also separated from ethics because it concerns singular things, namely actions.

Under Prudentia Locke grouped seven ends, happiness, tranquillity, health, wealth, power, reputation, favour. Some of these were cross-referenced to other headings (happiness to Theologia, health to Physica and power to Politia). Almost all the ends referred to the Aristotelian partition of goods in the first book of Nicomachean Ethics; 19 'Gratia' and 'Tranquilitas' were reminiscent of Cicero and Seneca's lexicon, with which Locke was utterly familiar in $1670 .{ }^{20}$ As for 'Gratia', he was closely

18

Aquinas, Summa Theologiae, IIa IIae, qq. 47-51.

19

Cf. Aquinas, Summa, Ia IIae, q. 2, art. 1-8.

20

Locke had read Cicero's De Officiis at Westminster Grammar School and had almost certainly used it and Cicero's Epistles in his moral teaching at Oxford in 1664 . He re-read De Officiis several times during the following years. As for Seneca, Locke read his Epistulae Morales at Westminister, as is confirmed by a number of manuscript notes 
acquainted with Seneca's De Beneficiis as well as Cicero's De Officiis, the two most popular classical works on beneficence in the seventeenth century: both insisted on exchanges of benefits as a necessary tool in order to obtain mutual favour and bind men together into concordia socialis, and both were particularly influential on Locke's political and moral thought. ${ }^{21}$ 'Tranquilitas' recalls Seneca's Stoic ideal of a life spent performing one's duties with virtue, tackling the vicissitudes of life with dignity and accepting the reversals of fortune with strength of mind (an attitude which requires a long training or àskesis, consisting for the most part in spiritual exercises such as writing, meditation and examination of conscience). This ideal seems to have been one of the bases of Locke's ethics, as is confirmed also by his classifications. The means needed to acquire Prudentia in Scheme 1 are self-knowledge, mastery of one's passions, knowledge of wits, seeking for counsel, directing of minds, economy, selling and accounting, and practice of manual arts; most of them are reminiscent of the Stoic idea of àskesis. ${ }^{22}$ In particular, 'Ingeniorum cognitio' (knowledge of wits) recalls a philosophical tradition steeped in Stoic ideals, which had two important

in MS. Locke e. 6, which also attest the reading of De ira. Locke possessed all of Cicero's and Seneca's works: cf. The Library of John Locke, ed. John Harrison and Peter Laslett (Oxford, 1965 [1971]), nos. 711-21q and 2615-16b. On Cicero's and Seneca's early influence on Locke, see John Marshall, John Locke: Resistance, Religion and Responsibility (Cambridge, 1994), 161-69.

21

Locke highly recommended the reading of De Officiis and insisted on the importance of teaching young pupils to be liberal and to show 'Respect, Esteem, and Good will, by paying to every one that common Ceremony and Regard which is in civility due to them': cf. Locke, Some Thoughts, §144, 203. Cicero's influence suffuses Some Thoughts, probably as a consequence of his heavy emphasis upon the restrictions of beneficence by means, worthiness and social ties, a feature which harmonized with Locke's moral and religious thought: cf. Marshall, John Locke, 314.

22

A neat distinction between Aristotelian-Thomistic and Stoic traits in Locke's classifications is of course an oversimplification: there are important elements of continuity between Aristotle and the Stoics' concept of phrónesis. See Danielle Lories, Le Sens Commun et Le Jugement du Phronimos. Aristote et les Stö̈ciens (Louvain La Neuve, 1998), 416-527. 
exponents in Joan Huarte and Francis Bacon. Economy is cross-referenced to wealth and corresponds to the Aristotelian art of household management, as is confirmed by the introduction, in a subsequent classification (MS Locke c. 28, ff. 157-58, henceforth Scheme 3 ) of the three Aristotelian sub-categories of household management (uxor, liberi, servi) after economy. ${ }^{23}$

As regards Theologia, in Scheme 1 Locke characterized the discipline as 'Historica vel Rationalis', two terms which he used to refer to a natural approach to theology based on the historical evidences contained in the Bible. ${ }^{24}$ The framework appears to be scholastic in nature. One of Locke's main sources of inspiration was probably the Anglican theologian Richard Hooker, who in the first book of his Laws of Ecclesiastical Polity adopted the Aristotelian-Thomistic hierarchy of being as the principal framework for his account of the relationship between God and Creation, and, within that, between different parts of the created order. $^{25}$ The first three subheadings under Theologia introduced the higher steps of the hierarchy ('Deus', 'Spiritus-Angeli',

23 Aristotle, Politics, 1235b 3-9; 1253b 16-20; as regards venditio and computo, see 1257b 25-30. Historia Mercatura might be interpreted as another reference to Aristotle's Politics: see Locke on Money, ed. Patrick Kelly (2 vols., Oxford, 1991), i, 94, n. 2.

24 Historical theology was prominent in the Reformation, with its emphasis upon the necessity of returning to the original sources of the Bible. Reformed theology was biblical and historical, being based on an exegetical as well as redemptive-historically sensitive method. Cf. Richard A. Muller, "Calvin and the "Calvinists": Assessing Continuities and Discontinuities Between the Reformation and Orthodoxy', Calvin Theological Journal, 30 (1995): 345-75; 31 (1996): 125-60.

25 The scholastic ordo scientiarum constituted a basic assumption in the Anglican liberal theological tradition, which had three of its main exponents in Richard Hooker, James Ussher, and Robert Sanderson. All three influenced Locke's thought considerably, but Hooker's influence was prevalent, as is confirmed by the many quotations from his work in the second treatise. Locke had read the Preface to the Laws of Ecclesiastical Polity before writing his English treatise on the magistrate in 1660, as can be inferred from a note he took from Henry Hammond's XAPI $\Sigma$ KAI EIPHNH, Or, A Pacific Discourse of God's Grace and Decrees (London, 1660). See MS Locke f. 14, 40, 42. Passages in Locke's Essays, particularly in the first, confirm that at the time of writing he had acquainted himself with the first book of Hooker's Laws. 
'Immortalitas-Anima separata'); as for the other subheadings, their order was representative of the natural progression of theological knowledge, which begins with the recognition of the existence of a divine being and proceeds to the acknowledgment of a law governing all human beings accessible through the light of reason. $^{26}$

In the fifth of his Essays on the Law of Nature, Locke affirmed that both God and the soul's immortality 'must necessarily be presupposed if natural law is to exist. For there is no law without a law-maker, and law is to no purpose without punishment'. ${ }^{27}$ This elucidates why, in Scheme 1, natural law came after 'Immortalitas' and 'Cultus': worship represented the natural consequence of the acknowledgment of God's existence, whereas immortality and the set of correlated beliefs (the soul separated from the body, resurrection, rewards and punishments in the afterlife) introduced those presuppositions necessary in order to affirm the existence of natural law.

As would have been proper to a natural approach to theology, under 'Revelatio' Locke listed only those means by which God offers extraordinary guidance to men, exercising what Hooker defined as a 'spirituall influence' (a mode of theological knowledge well attested in the Bible), ${ }^{28}$ and leaving aside those

26 In the incipit of the first of the Essays, Locke argued for the existence of God through both natural and revealed theology: 'God shows Himself to us as present everywhere and, as it were, forces Himself upon the eyes of men as much in the fixed course of nature now as by the frequent evidence of miracles in time past' (Locke, Essays, 109); subsequently he adopted a natural approach to theology, declaring that the existence of God could be acknowledged by perceiving the external world and its design.

27 Locke, Essays, 173. See also Locke's note 'Atheism' (1676), printed in Political Essays, 245: 'it is not reasonable for anyone to reject the doctrine of a deity, and the immortality of the soul, [which] if he will be true to himself he cannot part with, because he can raise some objections against it, till he hath established some other hypothesis upon surer foundations made out by clearer evidence and deduction of reason'.

28 For 'spiritual influence', see Richard Hooker, Of the Laws of Ecclesiastical Polity, II. ii. 1, in The Works of...Richard Hooker, ed. John Keble, rev. R. W. Church 
revealed truths which are above reason. These means are those by which, according to Aquinas, God testifies to such truths: they consist in the light of prophecy and in those special revelations attested in the Bible (miracles, predictions, dreams, visions, oracles). Similarly, the last two subheadings, 'Judaica: Creatio' and 'Christiana', relate to a form of revealed theology based on the Scriptures. They introduce the Jewish and the Christian accounts of Sacred History (the Old and the New Covenant).

The close relationship between ethics and lex naturae had been insisted on in the first of the Essays of the Law of Nature, ${ }^{29}$ where Locke drew a parallel between civil law as the object of jurisprudence, and natural law as the object of ethics. In the Essays, virtues were characterized as the content of the precepts of natural law $^{30}$ and identified with moral good. ${ }^{31}$ In Scheme 1 Locke seems to express a similar persuasion: ethics, natural law and virtues form a unity, which remains stable in his classifications at least until 1681.

The conception of natural law Locke referred to in Scheme 1 and in the Essays was quite different from Hooker's: the latter distinguished between the law of nature, which governs non-intellectual and non-voluntary natural agents, and the law of reason, which governs men, ${ }^{32}$ whereas Locke seemed closer to Aquinas and, above all, to the Stoics when he defined ethics in terms of living in conformity with natural law. Locke's preference for the Stoics' account of natural law, as well as for Stoic natural theology, is apparent in the Essays, ${ }^{33}$ which echo the Stoic and F. Paget (3 vols., Oxford, 1887), i, 290.

29

Locke, Essays, 115.

30

Locke, Essays, 129.

31 Locke, Essays, 109: 'we can equate with our law that moral good or virtue which philosopher in former times... have searched for'.

32 See Hooker, Of the Laws, I, iii-xv, in Works, i, 208-77.

33 Locke, Essays, 109-21. 
derivation of natural law from divine reason: the 'law of nature [Locke declares] can be described as being the decree of the divine will discernible by the light of nature and indicating what is and what is not in conformity with rational nature, and for this very reason commanding or prohibiting, ${ }^{34}$

The location of ethics under Theologia had been very common in accounts of natural theology since the Renaissance, where it marked a departure from the Aristotelian model of practical sciences including ethics, politics and economy. Almost all Reformed theological systems in the era of orthodoxy dealt with ethics to some extent: ${ }^{35}$ they usually began with an exposition of the doctrine of Scripture, including a discussion of the meaning and ethical import of the ten commandments, and ended with a treatment of the Last Things. A stronger ethical concern was particularly evident in Reformed authors such as Amandus Polanus and William Ames ${ }^{36}$ who, eschewing dogmatics, divided their treatises into two parts, the first dealing with doctrine and the second with practice. Such authors, who represented a model for several of their contemporaries, usually defined theology as a practical discipline in contrast to purely speculative sciences, and showed their dependence on Peter Ramus in matters of method. ${ }^{37}$

34

Locke, Essays, 111. On Locke's Stoicism see Victor Nuovo, 'Aspects of Stoicism in Locke's Philosophy', in Studies on Locke: Sources, Contemporaries, and Legacy, ed. Sarah Hutton and Paul Schuurman (Dordrecht, 2008), 1-25.

35 See Luca Baschera, 'Ethics in Reformed Orthodoxy', in A Companion to Reformed Orthodoxy, ed. Herman Selderhuis (Leiden, 2013), 519-52.

36 Locke did not possess Polanus's Syntagma Theologiae Christianae, only his Partitiones Logicae (Basle, 1601 [Library of John Locke, no. 2366]); as for Ames, he did not possess his famous Marrow of Theology but only his Declaration of ye Witnesses of God (London, 1681 [LJL, no. 84]). Locke probably bought only those works which he could not easily find in Christ Church Library.

37 In his Commentariorum de Religione Christiana (Frankfurt, 1576), Ramus defined theology as 'the doctrine of living well'; his disdain for Aristotle was particularly apparent in the area of ethics. In his view, the ethics of the Bible owed nothing to Aristotle's ethics (cf. Peter Ramus, Oratio de professione liberalium artium, Paris, 1563). 
As we shall see, the influence of these authors on Locke's theological thought is apparent in the classifications he wrote in the early 1680 s.

The location of ethics under Theologia implied its separation from Politia, a feature which was hardly compatible with Locke's political thought: in the sixth of the Essays, he declared that 'the laws of the civil magistrate derive their whole force from the constraining power of natural law'. ${ }^{38}$ The dependence of the norms of civil law on those of natural law would be emphasized much more by Locke in his later schemes, where he would adopt an Aristotelian model of classifying with reference to ethics and politics.

The outline of Theologia in Scheme 1 appears rather sketchy when compared to those of Prudentia and Physica, ${ }^{39}$ which contain many more topics; in 'Sapientia 72 ' 40 the number of topics listed under Theologia increases, even though many of them might have been added later (a hypothesis which is supported by the lack of space between some topics, as well as by the faint handwriting). The priority which was attributed to theology in Scheme 1 is compromised in 'Sapientia 72' by the introduction of another branch, Metaphysica, to which Locke assigns the number ' 1 ': Theologia is numbered ' 2 ' and Politia ' 3 ', even though they are both located above Metaphysica. This location suggests the numbers might have been added later, perhaps at the time when Locke was writing Scheme $3 .^{41}$ In that scheme the various

38

See Locke, Essays, 189; see also Essays, 183-85, where he argued that 'all obligation leads back to God', for it can be imposed only by someone who has 'right and power' over us, that is, by someone who possesses power 'by that right which a creator has over his own creation'. Since only the Creator has power, every other alleged authority can only have power by donation.

39 The headings of Physica in Scheme 1 were, respectively, 'Materia', 'Caelestia', 'Terrestria', 'Fossilia', 'Vegetabilia', 'Animalia', 'Homo', 'Anima', 'Corpus Humanus', and 'Sensus'.

40 MS Locke c. 28, f. $41^{\mathrm{rv}}$.

41 As James Buickerood suggested in 'The Natural History of Understanding: 
sciences are positioned according to their numbering in 'Sapientia 72 ', so that Metaphysica occupies the first place. This ordering is representative of the metaphysical thought of late Scholasticism, in particular that of the Spanish Jesuit Francisco Suárez. In his Disputationes metaphysicae, Suárez defined the study of metaphysics as a necessary prerequisite to theology, with God the principal object of metaphysics. The influence of Suárez on the metaphysical thought of seventeenth century Reformed theologians and philosophers such as Bartolomaeus Keckermann, Clemens Timpler, Gilbertus Jacchaeus and Franco Burgersdijck is well documented; Burgersdijck's Institutionum Metaphysicae was one of the main textbooks on metaphysics studied at Oxford in Locke's time. $^{42}$ The introduction of metaphysics in the latter's schemes, as well as the priority attributed to the discipline, might be traced back to his influence, or directly to that of Suárez.

Theologia is the discipline that was reworked the most in 'Sapientia 72': its subheadings became more numerous with the addition of a new item after 'Cultus'—'Mundus'—which completed the hierarchy of being in Scheme 1. The lack of space between the topics which preceded and followed this new subheading suggest that it might have been added later, together with the topics which pertain to it ('Aeternus' and 'Creatio'). An entry in Locke's journal for 26 April $1682^{43}$ shows that he was interested in confuting the atheistic hypothesis of the eternity of the world, probably as a consequence of his reading Ralph Cudworth's True Intellectual System. ${ }^{44}$ Since 'Mundus' reappears in Scheme 3, we may suppose its addition to 'Sapientia 72' dates to late 1681.

Locke and the Rise of Facultative Logic in the Eighteenth Century', History and Philosophy of Logic, 6 (1985): 173n.

42

Cf. W. H. Kenney, John Locke and the Oxford Training in Logic and Metaphysics, Ph.D. thesis (Saint Louis: St. Louis University, 1959). Burgersdijck's Institutionum Metaphisicae libri duo were published posthumously in 1640.

43 See The Life of John Locke: With Extracts from His Correspondence, Journals and Common-place Books, ed. Peter King (2 vols., London, 1830), i, 241-43.

44 Cf. the journal note for 18 February 1682 in Locke, An Early Draft of Locke's 
The items grouped under each subheading in 'Sapientia 72' are more numerous than those in Scheme $1 ;^{45}$ those grouped under the first subheading, 'Deus Optimus Maximus', ${ }^{46}$ refer to heathen idolatries, a topic of particular interest to Reformed theology (in contradistinction to Roman Catholicism). The three kinds of idolatry mentioned by Locke are reminiscent of Henry Hammond's analysis of the various meanings of the term 'Idol' in his Of Idolatry, ${ }^{47}$ though of course other influences are possible. ${ }^{48}$ The largest number of topics is added under the subheading 'Spiritus'. Some of these ('Lemures', 'Exorcismus', 'Obsessio Divinatio', 'Incantatio Magia Praestigia Necromantia Magia') might have been introduced later (perhaps before writing Scheme $3),{ }^{49}$ as is suggested by the location of some of them on the same line, the repetition of 'Magia' and the faint handwriting. All these

Essay, together with Excerpts from his Journals, ed. R. I. Aaron and Jocelyn Gibb (Oxford, 1936), 118, where Locke reports on his reading Cudworth's True intellectual System of the Universe and on Cudworth's reply to the atheistic argument ex nihilo nihil.

45 'Iudaica' might not represent a subheading in 'Sapientia 72', for the characters are smaller than those of the other subheadings: if so, the subheadings of Theologia would become seven, as in Scheme 3. The preference for the number seven-a Biblical number-might not be accidental.

46 In Essays, 108, Locke used the English equivalent of this Latin expression to designate God; the abbreviation D.O.M. was of common use in Christian Latin epigraphy.

47 Henry Hammond, Of Idolatry (Oxford, 1646), 1-6. Locke had written 'Idola' immediately below 'Deus Opt. Max.', and then deleted it.

48

In 1671 Edward Stillingfleet published A Discourse of the Idolatry practiced in the Church of Rome. An answer to Stillingfleet, entitled Catholicks no Idolaters, was published anonymously in the same year by Thomas Godden, but the controversy went on until 1679. In a journal entry for 15-20 July 1676, entitled 'Idolatry', Locke rejected Godden's arguments in defense of Roman Catholicism, and defined any performance of outward worship before an image as idolatrous. See Locke, Essays, 260-63.

49 'Exorcismus', 'Incantatio', 'Magia', 'Praestigia', 'Necromantia' are absent from Scheme 3, where Locke seems less interested in opposing the superstitious practices encouraged by papists than in criticising Anglican formalism. 
topics might refer to the disputation between Reformed and Catholic theologians concerning the doctrine of purgatory, and the possibility of dead men coming back to visit the living in the form of poltergeists; ${ }^{50}$ as may other items in 'Sapientia 72', they bespeak an approach to theology more sensitive to the teaching of the Reformation. Similarly, the absence of 'Sanctorum invocatio' from the list of topics collected under 'Cultus', as well as that of 'Miracula' from those grouped under 'Revelatio' ${ }^{51}$ seem to be related to the teachings of Reformed theology.

The addition of 'Psychopannuchia' 52 under the subheading 'Anima separata', which substitutes 'Immortalitas', is a reference to the Christian doctrine of mortalism, which incorporated the belief that the human soul is not naturally immortal and is uncomprehending during the time between bodily death and the Judgment Day resurrection. The substitution of 'Gehenna', which in Scheme 1 referred to the place to which the wicked are eternally damned, with 'Tartara' (the prison where, according to the

50

'Lemures' was a term frequently used by Luther as synonym for malevolent spirits (the malevolent version of Lares, according to Augustine's De civitate Dei); Luther criticized the Roman Catholic Church for encouraging superstitious belief in ghosts. Locke possessed the work by the Reformed theologian Ludwig Lavater, De spectris, lemuribus and magnis atque insolitis fragoribus (Geneva,1569 [LJL, no. 1691]), the third edition of 1683); he also possessed two editions of Calvin's Institutio Christianae religionis ( $L J L$, nos.570 and 571).

51 'Miracula' is written on the same line as 'Prophetia' and was probably added later, as is suggested by the fainter handwriting which renders it almost illegible. Reformed theologians criticized the Catholic doctrine of miracles: the absence of 'Miracula' from 'Sapientia 72' might be representative of this rejection. In Scheme 3, Locke once again introduces 'Miracula' under 'Revelatio'. Miracles and inspiration are the object of a journal note entitled 'Religion' (1681), printed in Political Essays, 27880 .

52 The term had been popularized by Calvin in his Psychopannychia (Orléans, 1534), where he confuted Luther's doctrine of soul sleep - the belief that the soul was unconscious in the intermediate state between death and the Judgment Day resurrection. Despite its etymology (psyché-pannychizein, 'conscious soul', as Calvin rightly intended it), psychopannychia was usually used as synonym for soul sleep. 
Scripture, fallen angels are only temporarily placed), ${ }^{53}$ might also be a reference to the doctrine of annihilation. Locke affirmed mortalism in The Reasonableness of Christianity, ${ }^{54}$ claiming that only the righteous would regain immortality at resurrection, the wicked would return to annihilation; the introduction of 'Psychopannuchia' in 'Sapientia 72' does not imply an earlier adhesion to this doctrine, for Locke also mentions transmigration of souls, a Platonic doctrine opposed to mortalism, ${ }^{55}$ and in Scheme 3 would introduce 'Purgatorium', substituting once again 'Tartara' with 'Gehenna'. Besides, both 'Transmigratio' and 'Psychopannuchia' seem to have been added later to 'Sapientia 72 '.

The mention of opposite doctrines under 'Anima separata' seems to be due to the use of the dichotomic technique, as is suggested, both in 'Sapientia 72' and Scheme 3, by the first two topics mentioned under this subheading ('Mortalis' and 'Immortalis'); however, this technique in 'Sapientia 72' is used mostly to criticize Catholic doctrines. The majority of the topics in 'Sapientia 72' appear to be sensitive to the teaching of Reformed theology and to their opposition to Roman Catholicism (an opposition which Locke felt strongly in 1672, and thereafter).

The close relationship between ethics and natural law is strengthened in 'Sapientia 72' by the conjunction 'sive'; the addition of 'Indifferentia' after 'Virtutes' and 'Vitia' creates a

\section{Peter 2:4.}

54

Locke, The Reasonableness of Christianity as Delivered in the Scriptures, ed. John C. Higgins-Biddle (Oxford, 1999), 6-11. See also Locke's manuscript additions, quoted by Higgins-Biddle (at lxxii). Annihilation is mentioned in a journal entry of 1680, entitled 'Of God's Justice' by Goldie and printed in Political Essays, 277-8, where Locke seems to prefer this doctrine as more in keeping with God's goodness.

55

Locke would refuse the Platonic doctrine of metempsychosis in Essay, II. xxvii. 6,332 , when discussing the identity conditions of the same man; its mention may be related to his reading of the Cambridge Platonists, in particular of Henry More's Antidote against Atheism which he was probably reading in 1677. See Jasper Reid, The Metaphysics of Henry More (Dordrecht, 2012), 136-37. 
closer conformity with the Stoic theory of value, which divided things into good, bad and indifferent. This addition was probably due to Locke's intention to emphasize such a fundamental notion in his political doctrine. ${ }^{56}$

The outline of Politia remains unvaried in 'Sapientia 72'; as for Prudentia, Locke only makes slight adjustments of which the most important is the introduction of a new topic among the 'Media', 'Morum rectitudo: Virtus Laus; Vitium Vituperium'. This item might have been added later, as the lack of space between the topics which precede and follow it and the smaller characters of the handwriting would suggest; further considerations support postdating the introduction of 'Morum rectitudo' in 'Sapientia 72', as we shall see when considering Scheme 3. In this, virtue and vice are no longer topics pertaining to theology. The link between virtues and natural law begins to dissolve.

\section{Scheme 2 and the other 'Adversaria' of 1677}

Scheme 2 (MS Locke f. 2, pp. 247-52) is an extract from a journal entry dated 4 September 1677 , and may represent the third of the adversaria written by Locke in that year. The first (MS Locke f. 15, pp. 119-20) consists of an outline entitled 'Adversaria', in Locke's pocket memorandum book for June 1677-June 1678; the outline has been crossed out with diagonal lines, indicating it had been copied elsewhere. ${ }^{57}$ The second scheme (MS Locke c. 28, f. 50, entitled 'Adversaria 19 Aug 77') is almost identical to that on pp. 119-20 of MS Locke f. 15, which might have been copied here with very few additions and later revised on pp. 122-23 of MS

56

Cf. Locke, Two Tracts, 123, 148-9, 208; idem, An Essay Concerning Toleration, and other writings on Law and Politics, 1667-1683, ed. J R. Milton and Philip Milton (Oxford, 2006), 276-78, 286.

57 There is another, incomplete outline entitled 'Adversaria' on p. 110, also crossed out. It contains only two headings, 'Credenda' and 'Agenda', with very few topics. Under the first, Locke lists 'Deo; Spiritus; Anima humana; Vita futura: Paradisus, Infernus', which are reminiscent of Scheme 1, whereas the items listed under 'Agenda' reappear in the 'Adversaria' on pp. 119-20 of the same manuscript. The distinction between 'Credenda' and 'Agenda' heralds the classification in Scheme 3. 
Locke f. 15, where another outline entitled 'Adversaria' is to be found. Scheme 2 is written in English, not in tabular form as are the other 1677 outlines; it is less articulated than the scheme in MS Locke f. 15, pp. 122-23, and might therefore have been written before it. A fifth outline, entitled 'Adversaria 12 Nov. 77' (MS Locke c. 28, f. 51), represents a reworking of MS Locke f. 15, pp. $122-23$, as would seem to be confirmed by a few additions and strong similarities. ${ }^{58}$

Scheme $2^{59}$ is written with a precise end in view, which Locke makes explicit in the opening paragraph. His aim was to find a method for identifying 'the principall parts or heads of things to be taken notice of' in 'reading books and making Adversaria', a purpose which was related to the attempt to devise a method of common-placing which Locke had been engaged in since the first years of his stay in France. ${ }^{60}$ To this purpose, in Scheme 2 he lists four headings, 'Adversaria philosophica', 'Adversaria Historica', 'Adversaria Immitanda', 'Adversaria Acquirenda'; at the very end of the classification, Locke adds another heading, 'Historica Physica referenda secundum species', whose scope is to collect 'the history of natural causes and effects'. This addition was probably meant to be placed after 'Adversaria Historica', as is shown by the other outlines written in 1677. The mention of 'Historia Physica' sounds Baconian; ${ }^{61}$ all the architecture of

58 There is another, incomplete outline in a loose sheet inserted into 'Adversaria 1661 ' between pp. 24 and 25, which contains two of the subheadings present in the adversaria written in 1677; however, there are some relevant differences concerning the various topics listed under them which render it difficult to establish when it was written. The outline might be a preparatory scheme for the adversaria; a transcription and description of it are to be found in Schuurman, The Digital Locke Project.

59 Goldie names this scheme 'Adversaria B' (Political Essays, 265-67); it was first published (misdated) in The Life of John Locke, i, 218-22.

60 Probably Locke had shown a brief Latin essay of his method of common-placing to his friend Nicolas Toinard, when they were both in Paris in 1677. See Toinard to Locke, Aug. 30, 1679, in Correspondence of John Locke, ii, 495.

61 According to Bacon, knowledge could be compared to 'pyramids, whereof history is the basis. So of Natural Philosophy, the basis is Natural History; the stage 
Scheme 2 appears, at first glance, to be modelled on Bacon's faculty psychology, ${ }^{62}$ yet the faculties to which Locke refers are not the Baconian ones, which were inspired by the scholastic division of inner senses (memoria, phantasia, vis cogitativa), but those on which Augustine structured his tripartite division of the human mind (intellect, memory, will), and to which Descartes referred in his Metaphysical Meditations.

In 1677 Locke was in France, reading Descartes and Jansenist authors such as Blaise Pascal and Pierre Nicole; in 1676, he had begun to translate Nicole's Essais de morale ${ }^{63}$ into English in order to publish them, but he completed the translation of only three of them, 'Discours contenant en abrégé les preuves naturelles de l'Existence de Dieu et de l'immortalité de l'Ame', 'De la faiblesse de l'homme', and 'Traité des moyens de conserver la paix avec les hommes'. ${ }^{64}$ In the second of these essays, Nicole dealt with the extent and kinds of human knowledge, distinguishing between knowledge of words, things and actions. Strikingly he insisted on the weakness of memory, understanding and will. As many Jansenists, in his Essais Nicole emphasized the feebleness of man's faculties and body, the corrupted nature of human beings as well as the brevity of their life, in order to dispose men to seek

next to the basis is Physic; the stage next to the vertical point is Metaphysic'. Cf. Francis Bacon, Of the Proficience and Advancement of Learning, Divine and Human, in The Works of Francis Bacon, ed. James Spedding, Robert L. Ellis, and Douglas D. Heath (15 vols., Boston, 1901), vi, 221.

62 See Bacon, Advancement, in Works, vi, 182; idem, De Augmentis Scientiarum, in Works, iii, 87. For Bacon's model of faculty psychology and its antecedents see G. T. Olivieri, 'Galen and Francis Bacon: Faculties of the Soul and the Classification of Knowledge', in The Shapes of Knowledge from the Renaissance to the Enlightenment, ed. Donald R. Kelley and Richard H. Popkin (Dordrecht: 1991), 61-82.

63 Cf. Jean S. Yolton, John Locke as Translator: three of the Essais of Pierre Nicole in French and English (Oxford, 2000). See also J. Lough, 'Locke's Reading during his Stay in France (1675-79)', The Library 8, (1953): 229-58.

64 Locke was forestalled by the appearance of a complete edition of Nicole in English (Moral Essays... Faithfully rendred into English from the Essais de Morale of P. Nicole, by a Person of Quality (3 vols., London,1677-80)). 
support in God alone and to act morally so as to obtain salvation; besides, he raised many of the objections about Calvinism which were voiced by most Latitudinarians and Arminians, supporting views that were broadly similar to theirs in maintaining both a deep sense of men's loss in the Fall and a belief that men had free will and needed to cooperate with a grace that worked largely through natural means.

It is highly probable that Locke held a number of views in common with Nicole at this time, as is confirmed by some notes he took in his journals; ${ }^{65}$ in particular, a lengthy entry written by Locke on March 6, 1677, entitled 'Study', ${ }^{66}$ brings together some themes Nicole treated in 'De la faiblesse de l'homme' (the limits of human knowledge with reference to the investigation of nature and the search for truth, the ancillary character of the study of words, the uncertainty of historical knowledge and the vanity of the knowledge of men's opinions), with the pedagogical views the latter had expressed in his treatise 'De l'education d'un prince'. ${ }^{67}$ Nicole recommended a Christianly oriented approach to learning, focusing on the knowledge of God and on the study and practice of morals; he also insisted on the necessity of not burdening memory by reading too many books, on the need for recreation and variation in matters of study, as well as on many other topics on which Locke's Some Thoughts Concerning Education had much to say in a similar line.

In 'Study', Locke outlined a sort of scheme purposing 'to marshal the parts of knowledge, and allot to anyone its place and precedency, thereby to direct one's studies' in order to secure

65 Cf. 'Atheism', 'Faith and Reason', 'Knowledge', 'Happiness' (all written in 1676); 'Understanding', (1677), printed in Political Essays, 245-6, 248-50, 250-1, 251-2, 260-4. See also Marshall, John Locke, 89-90, 131-37.

66

Printed in The Life of John Locke, i, 171-203, at 181.

67 Pierre Nicole, De l'education d'un prince (Paris, 1670; repr. as the second volume of the Essais in 1671). See $L J L$, no. 2085a. 
oneself 'happiness in the other world'. ${ }^{68}$ In the first place, he posited the knowledge of Heaven, which 'being our great business and interest...ought to take the first and chiefest place in our thoughts', whereas in the second place he highly recommended the study of prudence as a means to obtain 'happiness in the other world' and 'a quiet prosperous passage through this'; in the third place, Locke recommended study as the duty proper to those who had made it their profession, in conformity with God's commandment to work. The list was reminiscent of Aquinas's teaching, according to which the three fundamental laws of nature were the study of God, the preservation of oneself, and living in society; ${ }^{69}$ in the Essays, ${ }^{70}$ Locke declared these three laws 'embrace all that men owe to God, their neighbour, and themselves', and in 'Study' he restated this conviction. On the last pages of the note, Locke insisted on the great help afforded to memory by schemes 'of those sciences we employ our studies in': the many classifications he wrote during his life, as well as the adversaria written in 1677 , might be considered to be related to this purpose.

In Scheme 2, the various items are grouped with reference to the faculty or power 'cheifly exercisd'. The first heading, 'Adversaria Philosophica', refers to the 'knowledg of things their essence and nature, propertys causes and consequences of each species', a subject which is assigned to the faculty of judgment. The objects grouped under 'Adversaria Historica' (opinions and traditions concerning theological matters, rules and duties deriving from divine and human laws, religious and magical practices) are those which require the use of memory. As for 'Adversaria Immitanda', Locke declares that this 'head is... of most use' and concerns 'whatever wise practices are to be found either for governing of

68

Locke, 'Study', 180.

69

Aquinas, Summa, Ia IIae, q. 94, art. 2.

70

Locke, Essays, 156-59. 
policies, or a man's private conduct, or any beneficial arts employed on natural bodies for their improvement to our use'. The subheadings listed under 'Adversaria Immitanda' are 'Politica sive Sapientia civilis', 'Prudentia sive Sapientia privata' and 'Physica sive artes'; 'Adversaria Acquirenda' concerns trade. Both 'Adversaria Immitanda' and 'Adversaria Acquirenda' refer to 'practice or action', that is, to the sphere of will.

Like Scheme 2, two of the outlines written in 1677 ('Adversaria 19 Aug. 77' and 'Adversaria 12 Nov. 77') contain an explicit reference to the purpose of collecting the various items worth noticing in reading books. Unlike Scheme 2, the headings in the other adversaria advert more directly to the faculties or powers involved: in MS Locke f. 15, pp. 119-20 and 'Adversaria 19 Aug. 77', Locke lists three headings and their respective subheadings, 'Cognoscendorum: philosophica', 'Reminiscendorum: Historica civilia; Historica physica' and 'Agendorum: Immitanda: Moralia, Physica; Acquirenda', a partition which is maintained, with minor modifications, in the other 1677 outlines (MS Locke f. 15, pp. 122-23 and 'Adversaria 12 Nov. 77'). Under 'Historica civilia', in MS Locke f. 15, pp. 119-20 and 'Adversaria 19 Aug. 77' Locke collects all the topics which are subsumed under 'Adversaria Historica' in Scheme 2, adding other items including 'Virtutes' and 'Vitia'. In MS Locke f. 15, ff. 122-23, 'Historica civilia' is replaced by 'Historica moralia', albeit that the items listed under the latter are almost the same, whereas in 'Adversaria 12 Nov. 77' 'Historica Moralia' is replaced by 'Historica Religiosa', and the topics concerning civil law ('Instituta lege humana') are grouped separately under the reintroduced subheading 'Historica civilia'. These variations suggest Locke intended to separate the items concerning divine law categorically from those concerning civil law, ${ }^{71}$ a distinction which was at the root of the argument sketched in some notes on toleration he wrote in $1676 .{ }^{72}$

71 In MS Locke f 15, pp. 119-20, the topics listed under 'Historia civilia' are numbered in a different way from their disposition, a numbering which already heralds the separation of those concerning civil law from those relating to divine law; the disposition changes, conforming to the numbers, in MS Locke f. 15, pp. 122-23, and is 
In 'Adversaria 19 Aug. 77' and MS Locke f. 15, pp. 122-23, Locke introduced ethics and physics as disciplines pertaining to the heading 'Cognoscendorum', to which he added 'Metaphysica' in 'Adversaria 12 Nov. $777^{, 73}$ in the first two outlines, ethics was defined as the discipline determining the right distribution of goods ('Quicquid huiusmodi occurrit distribuendum in capita secundum varias rerum Species'), ${ }^{74}$ but in 'Adversaria 12 Nov. 77' Locke modified this definition, so that ethics became the discipline concerning those things which depend on human will ('qua pendent ex voluntate hominum ut Ethica'). Neither of the definitions referred to natural law: the first concerned the issue of distributive justice (a topic on which Locke was reflecting in 1677). ${ }^{75}$ The location of ethics among the objects pertaining to understanding entailed its separation from theological topics, which in all the adversaria are considered from a historical point of view as opinions and traditions concerning religious matters; all the other topics pertaining to Reminiscendorum, including those concerning civil law, are considered from this same perspective.

remodelled in 'Adversaria 12 Nov. 77 '.

72 See 'Toleration' (1676), in Locke, Essays, 274-75; cf. 'Obligation of Penal Law' (1676), in The Life of John Locke, i, 114-17.

73 In 'Adversaria 12 Nov. 77', 'Ethica' is numbered '3', 'Physica' '2', and 'Metaphysica' ' 1 ', though the order of writing is inverse. The numeration is respectful of the hierarchy between speculative and practical sciences, though probably contrary to Locke's list of priorities.

74 Under 'Cognoscendorum: philosophica' Locke writes: 'Whatever may lead to the knowledge of beings and their causes, properties, effects and consequences, in order to have true, clear and distinct ideas of them. Whatever is such that it has to be distributed among citizens, according to the different species of things: Ethics. Physics'. In MS. Locke f.15, pp. 119-20, the sentence is the same but there is no mention of ethics or physics.

75

Cf. 'Morality' (1677-8), printed in Political Essays, 268: 'Men therefore must either enjoy all things in common or by compact determine their rights. If all things be left in common, want, rapine and force will unavoidably follow in which state, as is evident, happiness cannot be had which cannot consist without plenty and security'. 
For Locke, natural law introduced the immutable decrees of God's will knowable through the natural light of reason. Accordingly there could not be any place for natural law in a scheme concerning men's mutable opinions.

Virtues and vices figured among the topics listed under 'Reminiscendorum' in MS Locke f. 15, pp. 119-20 and 'Adversaria 19 Aug. 77', precisely among the 'Instituta lege humana'. This location may be clarified by attending to what Locke had written in a 1676 journal entry, where he distinguished between virtues antecedent and consequent to the origin of society. Among the first, he cited the love of God, among the second 'obedience to magistrates'; in both cases, Locke affirmed, 'the rule and obligation is antecedent to human laws, though the matter about which that rule is, may be consequent to them'. ${ }^{76}$ The role played by human laws in determining the matter of virtues explains their positioning under the 'Instituta'.

However, in MS Locke f. 15, pp. 122-23 Locke removed virtues and vices from the 'Instituta' and located them under the 're vera variorum populorum' (real things concerning various populations), a further division added under 'Reminiscendorum: Historica moralia'. Finally, in 'Adversaria 12 Nov. 77', 'Virtutes' (though not 'Vitia') becomes one of the topics listed under 'Agendorum: Imitanda: Moralia'. Clearly, Locke was dissatisfied with the location of virtues among the objects pertaining to memory and intended to stress their pertinence to the sphere of action, as well as their moral significance. Besides, in this latter outline 'Virtutes' precedes 'prudentia', as the general does the particular. Prudence is now one of the moral virtues: its relevance progressively diminishes inside Locke's classifications.

To sum up, most of the variations in the adversaria concern moral topics, which are distributed among the different faculties. These variations do not seem to reflect Locke's growing

76 See Locke, 'Obligation of Penal Law', in The Life of John Locke, i, 114. The reference to property recalls the definition of the object of ethics in terms of issues concerning distribution in 'Adversaria 19 Aug. 77' and MS Locke f. 15, pp. 122-23. 
sympathies with hedonism, ${ }^{77}$ but rather his intention to emphasize the centrality of ethics and moral topics among the various objects of study. The relevance of the study and practice of morals in Christian life had been insisted on by Nicole in his Essais: the accent the latter put on the weakness of men's faculties (especially when faced with the 'inexplicable mysteries' of religion), was linked to his insistence on the dependence of men's eternal happiness upon their good actions. The argument implicit throughout the second of the essays translated by Locke was that men's salvation depends in significant part upon their own performance of morality, and not purely, as in some Calvinist thought, upon a predestined transference of Christ's righteousness apprehended by faith. The outlines of theology in the classifications Locke wrote in subsequent years put much more emphasis on moral duties than the previous ones.

\section{Scheme 3 (MS Locke c. 28, ff. 157-58)}

Scheme $3^{78}$ shows a manner of classifying similar to that in Scheme 1 and 'Sapientia 72', although the main headings here are seven (respectively, Metaphysica, Theologia, Politia, Prudentia, Historia, Physica and Semiotica sive de signis). The classification is undated and untitled, but there is a similar list in 'Adversaria 1661', pp. 290-91, dated 1681, the only substantial difference lying in the order of the disciplines. Scheme 3 seems to be a fair copy of the latter, and might have been written some time later.

Some additions under Metaphysica and, above all, the introduction of two new headings, Semiotica and Historia, make

77 In 'Morality' (Locke, Political Essays, 267-8), Locke depicted virtues as the result of men living in society and desiring 'the enjoyment of happiness and the absence of misery'. The hedonic turn was already visible in a previous entry, 'Pleasure and Pain. The Passions' (1676) and remained a persistent theme in Locke's later essays, 'Thus I Think' and 'Of Ethick in General'.

78 MS Locke c. 28, 157-58. The two pages consist of a tabular outline of a classification of the sciences, in the hand of Sylvanus Brounower (Locke's servant). Goldie names this outline 'Adversaria C' (Political Essays, 288); a transcription of Scheme 3 is given in Schuurman, The Digital Locke Project. 
Scheme 3 far richer than 'Sapientia 72'. Metaphysica occupies the first place, but in 'Adversaria 1661', pp. 290-91 it is still located below Theologia and numbered '1', as in 'Sapientia 72'. As has already been said, the precedence attributed to metaphysics with respect to theology might be due to the influence of Suàrez's model; however, the latter does not seem to have had a durable impact on Locke's classifications, probably because of the preference he accorded in later years to another model, inspired by Comenius's pansophic ideal of a unique wisdom reconciling both philosophy and theology, physics and metaphysics. The latter is replaced in Scheme 4 by pneumatics, which (again) follows theology. Great emphasis is placed in Locke's later works on the priority of theology intended as knowledge both of God and his creatures, the divine and the natural, with respect to the other sciences. ${ }^{79}$

As regards Politia, in Scheme 3 Locke maintained the distinction between 'Fundamenta', 'Forma' and 'Administratio' he had adopted in Scheme 1 and 'Sapientia 72', but he added some topics under 'Leges Civiles', 'Officium civile; crimen; Licitum'. The characterization of civil law in terms of civil duty, crime and licit action was already present in the 1677 classifications, where it seemed to create a symmetry between the institution of civil and divine law: the objects of the latter were religious duty, sin and indifferent action. ${ }^{80}$

The outline of Prudentia remains almost unchanged with respect to 'Sapientia 72', apart from minor variations such as the addition of a new topic under 'Morum rectitudo', 'Indifferens', which follows 'Virtus Laus' and 'Vitium Vituperium'. This

79 For elaboration, see the conclusion to this article, below.

80

In a 1678 journal entry entitled 'Law', Locke characterized the essence and role of civil law in terms of rights, rewards and punishments: 'A civil law is nothing but the agreement of a society of men either by themselves, or one or more authorized by them, determining the rights, and appointing rewards and punishments to certain actions of all within that society' (Political Essays, 269-70). The definition in Scheme 3 is clearly different, insisting on duties, not on rights. 
addition was probably due to Locke's intention to emphasize the confines of public morality, which do not encompass those actions not sanctioned either by natural or civil law. ${ }^{81}$ As has already been said, 'Morum rectitudo' might have been added later in 'Sapientia 72', at the time when Locke was composing 'Adversaria 1661', pp. 290-91: at the top of p. 290 of this latter outline, Locke wrote 'Sapientia est rerum humanarum divinarumque scientia', an expression which recalled the title he had given to the 1672 scheme. Locke might have used 'Sapientia 72 ' as a model when composing the outline in 'Adversaria 1661', pp. 290-91, making some important adjustments. In the latter, as well as in Scheme 3, there is no longer any mention of 'Ethica Sive lex naturae', which is substituted by 'Moralia'. The topics listed under this subheading are no longer virtue and vice-Locke might have thought it appropriate to find another location for them, adding for this purpose 'Morum rectitudo' under Prudentia. Some general considerations concerning the development of Locke's moral reflection support this hypothesis; I will summarize them in the following paragraphs.

The term rectitudo had been used by Locke in his Essays as a synonym for Cicero's notion of honestum, ${ }^{82}$ which incorporated wisdom and prudence, fortitude, decorum and justice. Decorum included temperance and moderation, but also courtesy, a social virtue apt to promote concordia socialis. Locke mentioned decorum in some of his adversaria ${ }^{83}$ as well as in a short outline in

81 See Locke, 'Obligation of Penal Laws', in The Life of John Locke, 115: 'All things not commanded or forbidden by the law of God are indifferent, nor is it in the power of man to alter their nature'. See also 'Scrupolosity' (1678), in The Life of John Locke, i, 205-6, where the existence of a sphere of indifferent actions is argued through recourse to God's benevolent design: 'I think God, out of his infinite goodness, considering our ignorance and frailty, hath left us a great liberty'.

82

Cicero, De Officiis, 1. 14. In the eighth of his Essays, 212-14, Locke opposed honestum to utile: this opposition is reminiscent of the second book of De Officiis.

83

'Decora' and 'Indecora' are mentioned under 'Historica civilia' in MS Locke f. 15, pp. 119-20, 'Adversaria 19 Aug. 1677', 'Adversaria 12 Nov. 77', and under 'Historica moralia' in MS Locke f. 15, pp. 122-23. Locke was rereading Cicero's De 
MS Locke 42, p. 22, dated 1679. In Scheme 3, 'Morum Rectitudo' might be intended as another reference to the notion of decorum, which in De Officiis incorporated an obligation to follow the established customs and conventions of one's community. The significance of the rectitude of morals increases in Locke's moral thought over time: in Epistola de Tolerantia, 'Morum rectitudo' introduces the sphere of public morality, which encompasses civil as well as religious obligations. ${ }^{84}$

In 1681 Locke was reading Hooker's Laws of Ecclesiastical Polity. He took numerous excerpts from the 1676 edition of Hooker's Works, all from the opening paragraphs of the first book of the Laws. ${ }^{85}$ The longest excerpt was from the third paragraph, ${ }^{86}$ where Hooker introduced a generic definition of law as 'any kind of rule or canon whereby actions are framed'. Perhaps consideration of Hooker's position contributed to the establishment of Locke's view that, while men arrive at moral ideas by a comparison of their actions to a rule, this rule can be threefold, i.e. divine law, civil law and the law of reputation or fashion. ${ }^{87}$ After quoting a passage from the first book of Hooker's Laws ${ }^{88}$ where it is said that man's observation of the law of his own nature is righteousness and his transgression of this law sin, Locke noted down some remarks of his own in his journal: 'The observation of the laws of one country officium civile, the breach of

Officiis in 1677: see MS Locke f. 2, ff. 361-2, which contains a note from the second book of that work.

84 See John Locke, Epistola de Tolerantia / A Letter on toleration, ed. R. Klibansky, trans. J. W. Gough (Oxford, 1968), 122: 'Morum rectitudo, in qua consistit non minima religionis et sincerae pietatis pars etiam ad vitam civilem spectat et in ea versatura animarum simul et republicae salus'.

85

MS Locke f. 5, ff. 69, 73-86.

86

MS. Locke f. 5, ff. 74-5.

87 See Essay, II. xxviii. 7, 352.

88

See Hooker, Of the Laws, I, ix, 1, in Works, i, 237. 
a penal law crimen or delictum; the observation of what in any country is thought [to be] enjoined by the law of nature virtus, the contrary vitium; the observation or omission of what is in credit and esteem anywhere laus and vituperium; licitum is what is not forbidden or commanded by the laws of the society. Indifferens what is so by all the other laws'. 89

In 'Adversaria 1661', pp. 290-91 and Scheme 3, rectitude of morals was characterized in terms which grouped together some of the notions Locke mentioned in his remarks on Hooker but kept separate there; he did not write 'Virtutis Laus; Vitii Vituperium' (virtues praised, vices blamed), yet he put one term next to the other (virtue, praise, vice, blame). Clearly, Locke might have been thinking of a link between them: in the short scheme written in 1679 (MS Locke c.42, f. 22), he listed various meanings of virtue in social contexts ('Virtus sive in Opinione...; In conversatione...; In persona...; In nascita et in ornamenta...'), ${ }^{90}$ a prospect which already suggested virtue should be identified with 'what is in credit and esteem anywhere'. In a journal note written in 1678, Locke declared that virtue was the name given to those actions recommended in societies, ${ }^{91}$ and in another note written in 1681 he insisted on the close link between virtue and reputation; ${ }^{92}$ in the

89

MS Locke f. 5, ff. 86-87. The passage is reproduced by von Leyden in his introduction to Locke, Essays, 68.

90 The scheme contains a list of topics, most of which were grouped into threes. The Ciceronian lexicon of De Officiis was probably Locke's source of inspiration for this scheme, as is shown by the mention of honestum and decorum.

91 See 'Virtue A' (1678), printed in Political Essays, 270-1: 'That virtue is but the name of such actions as are most conducing to the good of a society and are therefore by the society recommended by all means to the practice of the people seems to me very plain'.

92 See 'Virtue B' (1681), printed in Political Essays, 287: 'Virtue, as in its obligation it is the will of God, discovered by natural reason, and thus has the force of a law, so in the matter of it, it is nothing else but doing of good, either to oneself or others...But since man in society are in a far different estate than when considered single and alone, the instances and measures of virtue and vice are very different under these two considerations; for though, as I said before, the measures of temperance, to a 
Essay, he would affirm that 'the measure of what is everywhere called and esteemed Vertue and Vice is this approbation or dislike, praise or blame, which by a secret and tacit consent establishes it self in the several Societies'. ${ }^{93}$ Virtue or praise ${ }^{94}$ in the Essay is the name men give to actions which conform to the law of reputation, a conformity which they identify with the rectitude of morals: in Scheme 3, Locke seemed already to be collecting all the ingredients necessary to make this statement, whereas in 'Sapientia 72' virtues were still linked to ethics and natural law.

In Scheme 3, the subheadings listed under Theologia are respectively 'Deus Op. Max.', 'Spiritus', 'Anima separata', 'Mundus', 'Revelatio', 'Cultus', and 'Moralia'. Their order is different than in 'Sapientia 72': revelation comes before worship, and 'Moralia' is the final subheading. In order to write a coherent scheme of natural theology, Locke should have introduced revelation after ethics, as in Scheme 1 and 'Sapientia 72'; however, in Scheme 3 he adopted a different kind of approach, which he himself illustrated by writing, after 'Revelatio', 'Hactenus quid credendum sequitur q[ui]d agendum' ('up to this point what has to be believed, next what has to be done'). Locke separated doctrine from practice, following the example of Polanus and Ames: both, we have seen, defined theology as a practical discipline over against the purely speculative sciences, and both divided their systems into two main sections, faith (credenda) and good works (agenda). The appropriateness of such a division was confirmed, in their views, by the Holy Scripture, which on the one hand teaches the truth and on the other hand exhorts readers to live according to that truth. Both Polanus and Ames rejected the

solitary man, be none but those above mentioned; yet if he be a member of a society, it may, according to the station he has in it, receive measures from reputation and example.'

93 Essay, II. xxviii. 10, 353.

94 Essay, II. xxviii.11, 354: 'Vertue and Praise are so united that they are called often by the same Name'. 
Melanchthonian approach to ethics, which identified it with a philosophical discipline separated from theology and concerning outward manners directed towards keeping peace among human beings. Polanus in particular insisted on the close relationship between ethics and worship. He not only regarded the former as an aspect of the worship of God, but even maintained that the realm of ethics - that is, the performance of good works - coincided with that of worship. In a similar way, when translating Nicole Locke insisted on the relevance of moral practice in Christian life and in some manuscript notes written in 1681 he criticized the superstitious nature of several forms of outward worship. ${ }^{95}$ The many topics which Locke added under 'Cultus' in Scheme 3 ('Tempus Festi', 'Locus Templa', 'Petitoria', 'Expiatoria et averrucentia', 'Eucharistica', 'Confessio Iejunium', 'Gratiarum actio', 'Ministri', which combine with those already mentioned in 'Sapientia 72') ${ }^{96}$ are to be related to this criticism, which was directed against Roman Catholicism as well as Anglican formalism.

Like 'Cultus', 'Moralia' comes after revelation in Scheme 3, because its objects pertain to the sphere of action ('quid agendum'): to locate 'Ethica sive Lex naturae' after revelation would have been inconsistent with natural theology, therefore we may suppose the substitution of ethics with 'Moralia' in Scheme 3 expressed Locke's desire to remain within the bounds of this kind of approach, if not only this. Firstly, he might have intended to stress the relevance of the practice of moral duties in Christian life, as well as their identity with religious duties; secondly, he was probably interested in creating a symmetry between moral and

95

Cf. Locke, 'Defence of Nonconformity', MS Locke c. 34, pp. 142-60, where he attacked the superstitious ceremonies of Roman Catholics as well as the Anglican formalism, both responsible for the neglect of true Christian piety. Cf. also Locke, 'Religion' (1681), 'Reason, Passion, Superstition' (1681), 'Superstition' (1682), printed in Locke, Political Essays, 278-80 and 292-93.

96 Some of these topics ('Petitoria', 'Expiatoria', 'Averrucentia'), were already in the adversaria. 
civil duties. The topics listed under 'Moralia' ('Officium Religiosum; Peccatum; Indifferens') are-with the exception of the last - different from those which had Locke grouped together under 'Ethica sive Lex naturae' in 'Sapientia 72'. They had already been collected under 'Lege divina' in the various adversaria written in 1677, whereas in the short outline in MS Locke c.42 they were grouped under the heading 'Religio'. In a journal entry written in 1674, Locke defined 'Moralia' as 'the right management of our actions in respect of ourselves and others', ${ }^{97}$ whereas in another note written in 1681 he used the English equivalent 'moral things' as synonym for those truths whose knowledge depends on having 'a true Idea of God of him self as a creature of the relation he stands in to god and his fellow creatures and of Justice goodness law happinesse'. ${ }^{98}$ The topics listed under 'Moralia' in Scheme 3 presuppose the possession of these 'true ideas', among which is included the idea of a law. They show a clear symmetry with the items listed under 'Leges Civiles', one of the branches of Politia ('Officium civile; crimen; Licitum'). This symmetry seems intended to create a link between moral and civil duties: the substitution of 'Ethica sive Lex naturae' with 'Moralia' in Scheme 3 might also be related to this intention.

In 1681 Locke was reading Pufendorf's De Iure Naturae et Gentium. ${ }^{99}$ From some entries in his journal for 1681, we learn that during June his attention was drawn to the idea of the law of nature, ${ }^{100}$ and that he was reading Pufendorf's work carefully. This

97

See 'Civil and Ecclesiastical Power', printed in Political Essays, 216-21.

98

Locke, An Early Draft, 116 (the journal note is dated 26 June 1681).

99

See MS Locke f. 5, ff. 62, 67. For further discussion of Locke's reading of Pufendorf, see Marshall, John Locke, 201-4. Locke had purchased Pufendorf's works in France in the late 1670s, and may even have met Pufendorf in Paris sometime in $1677-79$.

100 For much of 1681 Locke lived near Oxford at the home of his friend James Tyrrell, who was then publishing his Patriarcha non Monarcha. In this treatise, Tyrrell appealed to the law of nature and referred to Grotius, Selden and Pufendorf. Locke's interest in the nature of law during 1681 might have been stimulated by Tyrrell's book 
reading provided him with some significant elements of arguments regarding the state of nature as a cooperative condition, and the reasons for establishing political society, which were used in the second treatise. Pufendorf firmly separated civil law from natural law: the first depended upon the legislation of political society, the second on reason alone. Locke strongly disagreed with Pufendorf on this point: he would insist that 'the Obligations of the Law of Nature cease not in society', and that 'the Law of Nature stands as an Eternal Rule to all Men, Legislators as well as others'. Already in his Essays on the Law of Nature Locke declared that the decrees of natural law represent the basis of ethics and the source from which civil law derived its binding force: his disagreement with Pufendorf was radical on this point.

In order to emphasize the dependence of civil laws on the decrees of natural law, Locke had to remove 'Ethica sive Lex naturae' from Theologia. This is the strategy he would adopt in Scheme 4, where he revised his manner of classifying completely. An alternative was to introduce a cross-reference between ethics

and by discussions between the two friends.

101 See John Locke, Two Treatises of Government, ed. Peter Laslett (Cambridge, 1960), II. xi. 135, 357-58. Locke continued: 'The Rules that they [Legislators] make for other Men's Actions must, as well as their own and other Mens Actions, be conformable to the Law of Nature, i.e. to the Will of God'. Positive laws 'are only so far right, as they are founded on the Law of Nature, by which they are to be regulated and interpreted' (Two Treatises, II. ii. 12, 275). For Locke, legislation involves making the laws of nature more specific and determining how to apply them to particular circumstances.

102 In Some Thoughts, Locke suggested the sons of gentlemen should read Pufendorf's De Officiis Hominis et Civis, and in both Some Thoughts and 'Some Thoughts Concerning Reading and Study for a Gentleman' he further recommended Pufendorf's De Iure Naturae et Gentium as the best work for instruction 'in the natural Rights of Men, and the Original and Foundations of Society, and the Duties resulting from thence' (Locke, Some Thoughts, 239 and 322). However, it was Cicero and the Bible that Locke recommended for teaching the precepts of morality, and Pufendorf only with careful restrictions. In Some Thoughts, he prescribed Pufendorf's work for teaching the duties subsequent to the foundation of society in a paragraph explicitly on politics $(\S 186)$, rather than in a preceding paragraph on morality, where Cicero was recommended. 
and politics: an undated outline of Theologia on the back endpaper of 'Adversaria 1661' suggests that he might have thought of something of this sort. The outline is more similar to Scheme 3 than to 'Sapientia 72 ' in some respects, among which the most relevant one appears to be the location of both worship and ethics at its very end, after revelation. ${ }^{103}$ Locke mentioned 'Ethica' (though not lex naturae) as the last subheading, and 'Virtutes. Vitia. Indifferentia. Licita' as its objects. What is worth noting is the introduction of 'Licita', which in Scheme 3 is one of the topics pertaining to 'Leges Civiles', among the objects of both 'Cultus' and 'Ethica', a clue to Locke's intention to create a link between ethics and politics. As for the absence of natural law from the outline on 'Adversaria 1661' back endpaper, the reason might be the same as in Scheme 3: to mention natural law after revelation would have been inconsistent with its historical priority to it. The disposition of the subheadings in the outline on 'Adversaria 1661' back endpaper heralded the distinction between doctrine and practice in Scheme 3.

\section{Scheme 4 and the division of the sciences in An Essay Concerning Human Understanding}

In his journal entry for June 26, 1681, mentioned above, Locke used the terms 'politie' and 'prudence' with a meaning rather different to those recorded in Scheme 1, 'Sapientia 72' and Scheme 3 . The two disciplines were closely connected: 'politie' concerned the 'well management' of public affairs, prudence that of private affairs, and both depended 'upon the various and unknown humors

103 The three items listed under 'Deus Opt. Max.' in the outline on the back endpaper of 'Adversaria 1661' were written in the same order as in Scheme 3, whereas their order was different in 'Sapientia 72'. 'Revelatio' was the penultimate subheading of Theologia in 'Sapientia 72', whereas in the outline on 'Adversaria 1661' back endpaper and in Scheme 3 it preceded 'Cultus' and 'Ethica-Moralia'. There were more topics under 'Spiritus' in 'Sapientia 72' than in the outline on 'Adversaria 1661' back endpaper: many of them were repositioned in the latter under 'Revelatio' ('Magia', 'Incantatio', 'Obsessio', 'Divinatio', 'Praestigia') and would disappear completely in Scheme 3. There are some topics under 'Cultus' in 'Adversaria 1661' ('Tempus', 'Locus') which were not present in 'Sapientia 72' but which did appear in Scheme 3. 
interests and capacities of men we have to do with in the world and not upon any settled Ideas of things'. The knowledge of 'politie' and 'prudence', Locke argued, should be fostered 'by the history of matter of fact and a sagacity of inquiring into probable causes and finding out an analogy in their operations and effects'. This 'knowledge' could not be rationally demonstrable because it was not grounded in 'right and true ideas', as morals was, but on matters of fact and opinions. Clearly, Locke was referring only to the administrative aspect of politics, not to Politia as an architectonic science: the identification of politics with administration was common in the political lexicon of his time, and he seemed now to conform to this lexicon. Similarly, prudence was identified with the ability to manage private affairs well (an ability which requires anticipation, not wisdom), as was also common in the lexicon of those times. ${ }^{104}$ Perhaps the ambiguous meaning conferred on prudence in the seventeenth century, oscillating between two poles (prudence as a cardinal virtue in religious language; prudence as foresight and shrewdness in common language), was one of the reasons for Locke's rethinking the relevance to attribute to Prudentia in his schemes, ${ }^{105}$ even though not the most important one. The most difficult task was to allocate a suitable place for ethics and natural law, which in Scheme 3 had been left out altogether, so as to emphasize their

104

The meaning of prudence had become very problematic in Locke's time: in a popular book by Baltasar Graciàn, Oràculo manual y arte de prudencia (Huesca, 1647), prudence appeared to be synonymous with 'slyness'. Locke owned Amelot de la Houssaie's version of this book, entitled L'homme de cour. Graciàn and Amelot's combined literary creation marked a new chapter in the history of prudence, for the work became the most effective vehicle for popularization of methods and practices of reason of state. Amelot's book was a reflection on a new competitive court society, in which courtly social rationality served to calculate human relations and prestige.

105

This rethinking is apparent in a letter Locke wrote to the Reverend Richard King on 25 August 1703, where he dwelt upon the virtue of prudence and the way to teach its rules to young gentlemen: 'every imprudent Action does not make a Man culpable in foro Conscientiae. The Business of Morality I look upon to be the avoiding of Crimes; of Prudence, Inconveniences'. This definition locates prudence on the borders of morality. See Correspondence of John Locke, viii, 57. 
priority with respect to politics and civil law. For Locke, the decrees of natural law represented the basis of moral as well as civil duties; in order to highlight their priority he might have thought it necessary to remove ethics from the outline of theology and to substitute an approach inspired by the theological systems of those Reformed theologians influenced by Ramus's anti-Aristotelianism with a more Aristotelian scheme.

Scheme 4 dates from $c .1686-7 .{ }^{106}$ On the top of the first page Locke wrote 'Physica' as a title, and immediately below he listed

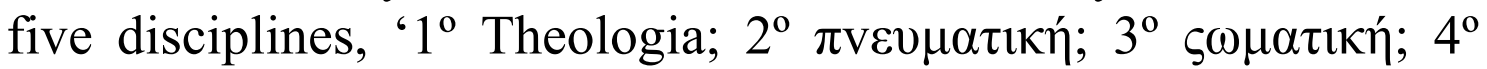

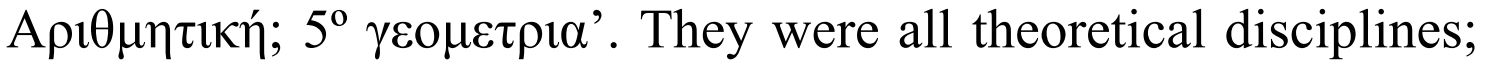
the mention of pneumatics and somatics (as well as that of 'Uranologia' a few lines below), was reminiscent of the lexicon of Johann Alsted's Encyclopedia. A German Calvinist, scholar and educator, Alsted was the author of several works expressive of pansophic ideals; the advanced model represented by the Encyclopedia exerted an enormous influence all over Europe. In this work he characterized metaphysics and pneumatics ${ }^{107}$ as theoretical sciences, along with physics intended as both generalis and somatica (the discipline investigating substantia corporea), and mathematics. ${ }^{108}$ The sciences which Locke listed at the beginning of Scheme 4 were the same as in Alsted's work, apart from the first, theology, which substituted metaphysics. In his Encyclopedia, Alsted adopted an organization of the sciences based loosely on Aristotelian distinctions between theoretical and practical philosophy, but he ranged well beyond the usual disciplines, subdividing the mathematical disciplines, for example,

106 MS Locke c. 28, ff. 155-56. A reference to the Essay (IV. xxiii. 20) appears at the top of $\mathrm{f} .155^{\mathrm{r}}$. The manuscript is in Locke's hand.

107 For the definition of 'pneumatica' as scientia de spiritu, cf. Johann Alsted, Cursus philosophici encyclopaedia libris XXVII (Herborn, 1620), II. x. Pneumatics was conceived of by Alsted as a section of metaphysics concerning immaterial spirits endowed with reason (God, angels, souls).

108

Cf. Alsted, Encyclopaedia septem tomis distincta (Herborn, 1630), I, table 32; theoretical disciplines are treated analytically in the third tome. 
not only into the traditional quadrivium but with equally ranked sections on cosmography, uranometry, geography and optics. All these sections were included in Scheme 4, under Somatica. Alsted was Comenius's teacher at Herborn and strongly contributed to shaping his project of educational reform, as well as his pansophic dream of a unique sapientia reconciling all the various branches of knowledge (a 'Christiana Philosophia' conceived of as a viva universi imago). Comenius invoked the Biblical commonplace that God had ordered the world according to number, measure, and weight to herald a pansophic encyclopedia, which would unite natural philosophy and theology. ${ }^{109}$ The list of disciplines which Locke grouped under Physica in Scheme 4 seem to be inspired by this same ideal, which went beyond the barriers of the scholastic ordo scientiarum.

Below the list of theoretical disciplines, in Scheme 4 Locke rewrote ' $\Sigma \omega \mu \alpha \tau \iota \kappa \eta '$ ', a heading under which he collected various topics pertaining to Physica in his previous classifications. On the following page, Locke introduced the new heading $\Pi \rho \alpha \kappa \tau \iota \kappa \eta$ and its subheadings, 'Ethica', 'Politica', 'Prudentia civilis', 'Prudentia monastia' and 'Oeconomia'. The definition of ethics was formulated in terms of natural law theory: the object of ethics

109

Cf. J. A. Comenius, Pansophiae Prodromus, In quo admirandi illius \& vere incomparabilis Operis, Necessitas, Possibilitas, Utilitas, solide, perspicue, \& eleganter demonstratur (London, 1639), sec. 40. Locke possessed Comenius's Physicae ad lumen divinum reformatae synopsis ( $L J L$, no. $819 \mathrm{~b}$ ), together with his various editions of the Janua linguarum (LJL, nos. 817-19a).

110

Between 1683 and 1689 Locke was in Holland, writing to Edward Clarke on the subject of education. His interest in Comenius's and Alsted's works might have been motivated by the importance of their educational activity, as well as by many more motives including their interest in the kabbalah, a subject which attracted Locke's curiosity in the late 'eighties in part because of his friendship with Mercurius van Helmont. There are several references to van Helmont in Locke's correspondence, especially from 1687. See in particular Correspondence of John Locke, iii, 399-405, which contains Christian Knorr von Rosenroth's observations on the Abrégé of Locke's Essay, probably given to Locke by van Helmont. Cf. Allison P. Coudert, 'John Locke and Francis Mercurius van Helmont', in James E. Force and David S. Katz (eds.), Everything Connects: In Conference with Richard H. Popkin: Essays in His Honor (Leiden, 1999), 87-113. 
consists in living in accordance with the rules given by God to every man. Politics comes after ethics: moral law represents the normative foundation and universal standard for positive law.

The definition of politics seems to combine the architectonic and administrative aspects, since it refers to both the creation of societies and the way of governing them. Prudence is divided into 'Prudentia civilis', concerning man as a member of a society, and 'Prudentia monastia', concerning man as a single individual. This distinction might be due to Locke's desire to emphasize the relevance of social virtues for the well-being and safety of organized societies. Civil prudence is representative of Locke's Ciceronian ideal of an ethics characterized by courtesy, civility and humanity, an ideal expounded in Some Thoughts Concerning Education. ${ }^{111}$ Some of the topics listed under prudence in Scheme 4 (comitas and subjection of the passions) relate to Cicero's concept of decorum; 'hominum cognitio' refers to the study of human individual and social characters, a subject whose relevance in the seventeenth century was attested by the popularity of Jean de La Bruyère's Caractères. ${ }^{112}$ The significance prudence had in Locke's previous classifications as a dianoetic virtue was clearly diminished: eternal happiness was the end of 'Ethica', whereas 'Oeconomia' stood on its own under Practica, with a rich set of arts as its subheadings.

Scheme 4 included three headings, Physica, Practica and Semiotica; an identical partition is to be found in the division of the

111

According to Oestreich, Prudentia civilis was the major concept in politics in the seventeenth century; the doctrine stressed obedience and discipline as conditions of a well-ordered state and taught the individual to regulate emotions and subordinate himself politically. See G. Oestreich, Neostoicism and the Early Modern State, ed. Brigitta Oestreich and H. G. Koenigsberger, trans. David McLintock (Cambridge, 1982), 162-65. Locke's definition of prudentia civilis in Scheme 4 seems to be rather different to that in vogue in his time.

112 Jean de La Bruyere, Le caractères ou les Moeurs de ce siècle (Paris, 1688); cf. Locke, 'Some Thoughts concerning reading and Study for a Gentleman' (Locke, Some Thoughts, 325), where he recommended the reading of La Bruyere to young gentlemen. 
sciences at the end of the Essay. ${ }^{113}$ In the latter, physics ( $\varphi v \sigma 1 \kappa \eta$ ) occupies the first place; its definition somewhat illustrates the sense of the list of disciplines collected under Physica in Scheme 4. The object of physics, Locke writes in Essay, is 'bare speculative Truth, and whatsoever can afford the Mind of Man any such, falls under this branch, whether it be God himself, Angels Spirits, Bodies, or any of their Affections, as Number, and Figure, etc'. ${ }^{114}$ Hence, physics includes both somatics and pneumatics-its objects are not only material but also spiritual bodies. Similarly, in Some Thoughts Locke would declare that 'Natural philosophy being the Knowledge of the Principles, Properties, and Operations of Things, as they are in themselves, I imagine there are Two Parts of it, one comprehending Spirits, with their Nature and Qualities; and the other Bodies. The first of these is usually referr'd to Metaphysics', even though, Locke goes on to say, there are other names for the discipline, probably alluding to pneumatics ${ }^{115}$. Hence, metaphysics is conceived of as a part of physics; the absence of metaphysics and theology from the division of the sciences in the Essay might imply their being implicitly subsumed into physics, as in Scheme 4.

The definition of Practica in the Essay ('the Skill of Right applying our own Powers and Actions, for the Attainment of things good and useful') is reminiscent of that of phrónesis in Nicomachean Ethics. ${ }^{116}$ Locke mentions only one subheading under this heading, Ethicks, as 'the most considerable'. The business of ethics is 'the seeking out of those Rules, and Measures of human Actions, which lead to Happiness, and the Means to

113

Essay, IV. xxi. 1-4, 720.

114

Essay IV. xxi. 2, 720.

115

Locke, Some Thoughts, §190, 245.

116 Aristotle, Nicomachean Ethics, 1140a 25-7: 'it is thought to be the mark of a man of practical wisdom to be able to deliberate well about what is good and expedient for himself'. 
Practice them'; its end is 'not bare Speculation, and the Knowledge of Truth; but Right, and a Conduct suitable to it'. As in Scheme 4, in the Essay Locke gives precedence to ethics (politics is not mentioned), while the practical dimension of the discipline is apparent in the reference to the 'Means to Practice' moral rules.

The division of the sciences in the Essay recalls Nicole's partition of knowledge into three main branches, that is knowledge of things, actions and words; more specifically, it attests the desire to unify the various sciences into a unique sapientia, a project which was heralded by the title Locke had given to the classification written in 1681, 'Sapientia est rerum divinarum humanarum scientia'. Pansophism could be to some extent reconciled with Aristotelianism (as was shown by Alsted's Encyclopedia); clearly, the possibility of highlighting the priority of ethics and natural law with respect to politics and civil law in Locke's classifications depended on the adoption of an Aristotelian scheme, that is, on their removal from the outline of theology. This was the strategy he adopted both in Scheme 4 and in the Essay.

However, there are reasons to suspect that Locke was not fully satisfied with this strategy: in order to emphasize the dependence of moral and civil duties on theological presuppositions, ${ }^{117}$ ethics had to be included among the branches of theology, as it was in his previous classifications. This inclusion was reaffirmed in a later outline of theology Locke wrote in 1694, which resembles his earlier schemes in some respects even as it introduces some important innovations.

\section{Conclusion: 'Adversaria Theologica 94', ff. 1-7}

In Of the Conduct of Understanding, ${ }^{118}$ Locke emphasizes the priority of theology with respect to the other sciences, insisting on its all-encompassing nature. Let him speak for himself:

117 See Essay, IV. x. 7, 622, where he declares that the existence of God represents 'so fundamental a Truth, and of that Consequence, that all Religion and genuine Morality depend thereon'.

118 John Locke, Of the Conduct of the Understanding, ed. Paul Schuurman 
There is indeed one Science (as they are now destinguishd) incomparably above all the rest where it is not by Corruption narrowed into a trade or faction for meane or ill ends and secular Interests, I mean Theologie, which conteining the Knowledg of god and his creatures, our duty to him and our fellow creatures and a view of our present and future state is the comprehension of all other knowledg directed to its true end, i. e. the honour and veneration of the Creator, and the happynesse of man kinde. This is that noble Study which is every mans duty and every one that can be called a rational creature is capable of. The workes of nature and the words of Revelation displai it to mankinde in Characters so large and visible that those who are not quite blind may in them read and see the first principles and most necessary parts of it and from thence as they have time helps and Industry may be inabled to go on to the more abstruse parts of it and penetrate into those infinite depths filld with the treasures of wisdom and knowledg.

In the Conduct, the study of theology was characterized as necessary in order to accommodate all the other subjects into an appropriate order and as capable of expanding the mind, especially with the addition of revelation. This study represented a duty to be practiced by individual Christians, a conviction Locke had already expressed in the early Essays and in his note 'Study'. The project of harmonizing philosophy and theology found its mature formulation in the Conduct. One of the milestones of this project was an outline of theology Locke wrote during the last years of his life, when he devoted much of his time to theological studies. ${ }^{119}$ The outline is to be found in one of his commonplace books, 'Adversaria Theologica 94'. ${ }^{120}$ It shows what Locke considered in those years to be the extensive scope of theology. The kind of

(Doctoral dissertation, University of Keele, 2000), 193.

119

Writing to Philippus van Limborch on 11 December 1694, Locke remarked that he intended to devote himself for the most part to these studies: see Correspondence of John Locke, v, 237-39. On Locke's theological studies in the later years, see the 'Introduction' to John Locke, Writings on Religion, ed. Victor Nuovo (Oxford, 2002).

120

MS Locke c. 43, ff. 1-7. A transcription of this outline is in Locke, Writings on Religion, 21-23; see also the Introduction, xxix-xxxiii. 
approach to the discipline typical of the previous classifications, which was indebted to Reformed theology in the stress put on the practical nature of the discipline, gives way to a philosophical approach $^{121}$ based on a close relationship between theology and physics. The definition of Physica in the Essay already highlighted the possibility of a physical approach to the objects of theology, a possibility which might have represented for Locke the right way to provide a solid foundation to its most controversial questions. This kind of approach could provide an antidote to the unavoidable errors deriving from any attempt to interpret revealed Truths, which being 'conveyed to us by Books and Languages, are liable to the common and natural obscurities and difficulties incident to Words'. ${ }^{122}$

The subheadings of Theologia in 'Adversaria Theologica' are, respectively, 'Deus', 'Spiritus', 'Anima humana', 'Materia', 'Mundus aspectabilis', 'Systema nostrum', 'Homo', 'Christus', 'Spiritus Sanctus', 'Revelatio', 'Biblia' and 'Ethica sive Hominis officium'. Several are new with respect to the previous classifications. 'Mundus', 'Materia' and 'Homo' were already in the outlines of Physica in Locke's previous schemes; ${ }^{123}$ the addition of 'Christus' and 'Spiritus Sanctus' might be taken as a clue to Locke's interest in the Unitarian controversy, well evidenced by his library and correspondence. ${ }^{124}$

121 See Locke to Limborch, 29 October 1697 (Correspondence of John Locke, vi, 243-46), where he affirmed that the theological question the latter was inquiring into, concerning the way to prove God's uniqueness, could be approached philosophically, that is in physical terms: "the mind must be raised to a somewhat higher level and separated from the ordinary manner of philosophizing if anyone wants to prove it philosophically or, if I may speak thus, physically'.

122

Essay, III. ix. 23, 490.

123

The topics listed under 'Materia' ('creata; Qualis; Quanta'), as well as those under 'Mundus aspectabilis'; ('Antiquitas. Systema nostrum: Sol; Planetae; Terra') are new with respect to the outline of Physica in Scheme 3. Only 'Terra' was present in this latter scheme.

124

See Marshall, John Locke, 419-20; cf. John Locke, A Paraphrase and Notes on the Epistles of St. Paul, ed. Arthur W. Wainwright (2 vols., Oxford, 1987), i, 
'Cultus' and the correlated entries are absent from 'Adversaria Theologica', a clue to Locke's intention to approach theology in a way different from the previous schemes. The items listed under each subheading are, for the most part, different from those grouped in the previous schemes. In 'Sapientia 72' and Scheme 3, Locke mentioned heathen idolatries under 'Deus', whereas in 'Adversaria Theologica' he introduced a list of God's attributes, 'Unus; Trinus; Omnipotens; Omniscens; Benignus'. These were the main attributes which the Scholastic tradition assigned to God. ${ }^{125}$ The many spiritual entities which were grouped under 'Spiritus' in Scheme 3 ('Angeli; Daemones; Spectra; Lemures; Obsessio'), made way in 'Adversaria Theologica' for a series of topics concerning the origin, nature and different kinds of spiritual beings, their Fall and punishment ('Quando creati; Natura; Species; Facultates; Lapsus; Crimen; Supplicium; Potestas'). ${ }^{126}$

The topics listed under 'Anima separata' ('Preexistentia; Revolutio; Creatio; Traductio') ${ }^{127}$ are less numerous than in Scheme 3, for most of those which were collected under this subheading are located under 'Homo' in 'Adversaria Theologica'. Under this head, Locke mentioned some topics concerning men's faculties ('Intellectus', 'Voluntas', 'Sensus', which were already in the outline of physics in Scheme 3), as well as some topics concerning men's moral condition ('Innocens', 'Lapsus', 'Libertas', 'Peccatus Adami', which were in none of the previous classifications). To these Locke added some topics concerning

Introduction. There is clear evidence that Locke was taking notes from a number of Unitarian works when, in 1694, he started 'Adversaria Theologica', for he recorded many notes from Unitarian works on the following pages of the notebook.

125

On the persistence of this tradition in Locke's thought see von Leyden's Introduction to Locke, Essays, 36.

126

'Facultates' was already in the outline of Physica in Scheme 3.

127 After these topics, Locke introduced 'Anima brutorum', which was listed under the subheading 'Animalia' of Physica in Scheme 3. The item is kept separate from the previous ones. 
men's final destination ('post mortem: pseuchopannuchia; Resurrectio; Paradisus; Gehenna; Annihilatio'). There is no longer any mention either of 'Purgatorium', which appeared only in Scheme 3, or 'Trasmigratio', which was in both Scheme 3 and 'Sapientia 72'. The presence of 'Annihilatio', which was in none of the previous classifications, might indicate Locke's adhesion to mortalism, even though he also mentions 'Gehenna' and two doctrines incompatible with mortalism (the pre-existence and revolution of souls). ${ }^{128}$ Their presence might be due simply to the use of the dichotomic technique, which was already attested in the previous classifications, or else to Locke's intention to approach theology historically, giving a survey of the various Christian doctrines.

The last head in the outline of Theologia is 'Ethica sive Hominum Officium'; the position of this subheading is identical with that of 'Moralia' in Scheme 3. There is no mention of lex naturae: the only laws cited in 'Adversaria Theologica' are 'Lex Mosaica' and 'Evangelium', both located under the head 'Biblia'. The object of ethics is characterized in terms of duties, not of virtues (a notion which was already absent from the outline of theology in Scheme 3). Locke lists several kinds of duties (officia), ordering them hierarchically according to their object ('Deum; Spiritos bonos; malos ${ }^{129}$; Rempublicam; Magistratus; Parentes; Conjuges; Liberos; Affines; Dominos; Servos; Herum; Famulos; Vicinos; Homines; Seipsum'). In his earlier classifications Locke had only distinguished between religious and civil duties, whereas in 'Adversaria Theologica' he classifies them in many more categories (religious duties; civil duties; duties relating to the household distinguished in familiar duties, duties towards those

128

The other topics relating to human soul concern its materiality and corruptibility, a position that Locke seems to favour in 'Adversaria Theologica': see Nuovo's 'Introduction' to Locke, Writings on Religion, xxx.

129

As regards the duties concerning evil spirits, Locke was probably referring to what St Paul affirmed in Ephesians 6:12, where he recommended Christians should fight against 'spiritual wickedness in high places'. 
who are equally ranked and those who occupy a higher or lower position; duties towards neighbours, mankind and the self). The list is modelled on Cicero's teaching in De Officiis. ${ }^{130}$ in Some Thoughts Concerning Education Locke highly recommended the reading of De Officiis in order to 'be informed in the Principles and Precepts of Vertue'. ${ }^{131}$ Cicero's account of duties-especially civil duties, but also those of natural fellowship-was particularly congenial to Locke, although in The Reasonableness of Christianity he noted its incompleteness in view of its failure to recognize obligations to God. ${ }^{132}$ To Locke's mind, the Gospel was the perfect book of offices; ${ }^{133}$ so it was that in 'Adversaria Theologica', as well as in Scheme 3, ethics came after 'Revelatio' and 'Biblia', directly after 'Evangelium'.

We may suspect that the difficulties Locke had encountered in attempting a full exposition of the content of natural law, already apparent in the unfinished 'Of Ethick in General', ${ }^{134}$ were the real

130

Cicero, De Officiis,1. 50-58.

131

Locke, Some Thoughts, §185, 239.

132

In The Reasonableness of Christianity Locke insisted on the incompleteness of Cicero's ethics, which did not acknowledge an obligation to God: he argued that various heathen philosophers had articulated significant portions of ethics, but that they had not been able to produce sufficient reasons for men to obey their precepts in terms either of obligation or of motivation. Cicero was listed among these philosophers. See Locke, Reasonableness, 150.

133

See Locke to William Molyneux, April 5, 1696, Correspondence of John Locke, vi, 593-96, at 595: 'when I consider, that a book of Offices, as you call it, ought not to be slightly done...I am in doubt whether it would be prudent, in one of my age and health, not to mention other disabilities in me, to set about it. Did the world want a rule, I confess there could be no work so necessary, nor so commendable. But the Gospel contains so perfect a body of Ethicks, that reason may be excused from that enquiry, since she may find man's duty clearer and easier in revelation than in herself'.

134

Locke, 'Of Ethick in General' (MS Locke c. 28, ff. 146-52), printed in Political Essays, 297-304. Composed shortly before the publication of the first edition of the Essay, 'Of Ethick' is a comprehensive account of Locke's thoughts on morality attached to the paper containing Scheme 4; it bear marks by Locke indicating that it was to become chapter 20 of the fourth book of the Essay, but he left it incomplete. Locke writes of the proper and true foundation of the rules of good and evil, and refers to the 
causes of its absence from 'Adversaria Theologica'. Although showing himself to be a faithful advocate of natural law and stressing his belief in an eternal and objective morality, in the Essay Locke had not developed the details of his natural law theory nor had he explained the grounds on which it rested. The hedonistic views he had formulated in the Essay, as well as his philosophy of language, made it difficult to attempt a full exposition of natural law, for they were hardly compatible with his earlier doctrine on moral goodness as the name for 'the rectitude of actions, which is nothing but the conformity of the actions of men to some rule'.

It is difficult to finally determine the degree to which Locke was aware of this incompatibility: the absence of natural law from 'Adversaria Theologica' might be interpreted as a clue to the difficulty he had found in allocating a place for it inside his outlines of theology since 1681, when he had begun to depart from the naturalistic approach to the discipline adopted in Scheme 1. By Scheme 3, Locke had substituted ethics with 'Moralia' in order to underscore the relevance of the performance of religious or moral duties in the Christian life. In 'Adversaria Theologica' he reintroduced ethics, reshaping its content in terms of duties in order to emphasize the same concept. Natural law was absent from both these schemes, probably for the same reason: both presupposed a distinction between 'credenda' and 'agenda' which was impossible to accommodate to the naturalistic approach to theology which had for so long shaped Locke's classifications of knowledge.

\section{Gabriele D’Annunzio University of Chieti-Pescara}

will of a lawgiver and the law of nature as prerequisites for the knowledge of these moral rules. After remarking that the sovereign law-maker is God, Locke goes on to say: 'The next thing then to show is, that there are certain rules, certain dictates, which it is his will all men should conform their actions to, and that this will of his is sufficiently promulgated and made known to all mankind'. Here the paper ends.

135

Locke, Essays, 173, 185. See also 'Voluntas' (1693), printed in Political Essays, 321, where he differentiates between moral rectitude and moral goodness. 


\section{Appendices}

\section{Scheme 1}

'Adversaria 1661' (MS Film 77, ff. 1-2)

[f. $1^{\mathrm{r}}$ ]

Deus

Spiritus

Immortalitas

Anima [separata $>$ Immortalitas]

Cultus [ritualis]

Ethica

Revelatio

Judaica

Christiana

[f. $\left.1^{\mathrm{v}}\right]$

Politia

Fundamenta Ius paternum. [Ce]

Consensus Populi

Forma

Monarchia

Aristocratia

Democratia

Mixta

Constitutiones fundamentales

Angeli Oracula

Creatio

\section{Theologia. Historica vel Rationalis}

Anima seperata. Resurrectio. Praemium. Poena. Coelum. Gehenna

Ritus. Ceremoniae. Sanctorum invocatio. Sacerdotes

Lex na[tur]a Virtutes et vitia

Miracula Vaticinia Insomnia Visiones Enthusiastica Prophetia

[f. $2^{\mathrm{r}}$ ]

Prudentia

Finis est

Felicitas Coelestis quae pertinet ad Theologiam

Tranquilitas

Sanitas

Opes

Potestas quae pertinet ad Physicam

${ }_{2}$ Fama quae pertinent ad oeconomiam

Gratia quae pertinet ad Politiam 
[f. $\left.1^{\mathrm{v}}\right]$

Administratio [f. $2^{\mathrm{r}}$ ]

Media ad hos fines

Sui cognitio.

[Passionum imperium suarum]

In passiones suas imperium

Ingeniorum Cognitio

Consiliorum [observatio]>indagatio.

Animorum Gubernatio Rhetorica.

Economica

Venditio et Comptio Historia mercatura cuiuslibet

$$
\because \div \div \div \div
$$

\section{'Sapientia 72' (MS Locke c. 28, f. 41 ${ }^{\mathrm{r}-\mathrm{v}}$ )}

\section{[f. 41v] 2. Theologia}

Deus Opt[imus] Max[imus]

Idola

Dii factitii sive Idola

Dii inventi sive res na[tur]ales pro diis habita

Dii Adscitij sive homines in deos relati. Heroes.

\section{Spiritus}

Angeli

Daemones

Spectra

Lemures

Exorcismus

Obsessio Divinatio

Incantatio Magia Praestigia Necromantia Magia

Anima humana separata

Mortalis

Immortalis

Praemium Coelum

Poena. Tartara.

Resurrectio. Transmigratio

Psychopannuchia

Mundus

Aeternus

Creatus

\section{Politia}

\section{Fundamenta}

Ius paternum.

Consensus Populi

\author{
Forma [Monarehia] \\ Monarchia
}

Aristocratia

Democratia

Mixta 
Cultus

Ritus

Ceremonia

Sacerdotes

Sacraficia Oblationes

Preces

Laudes

[Mu]

Ethica sive Lex na[tur]a

Virtutes

Vitia

Indifferentia

Revelatio

Prophetia. Miracula.

Vaticinia

Oracula

Insomnia

Visiones

Enthusiasmus

Judaica

Creatio

Christiana
Constitutiones Fundamentales

\section{Administratio}

Leges Civiles

\section{Ens}

\section{Metaphysica}

Attributa transcendentalia et affectiones

Essentia

Existentia

Unitas

Duratio

Relatio

[f. $\left.41^{\mathrm{r}}\right]$

Prudentia

Finis

Faelicitas

Aeterna et coelestis quae pertinet ad theologiam Mundana

Tranquilitas

Sanitas vid[e] Physicam

Opes

Potestas vid[e] Politiam

Gratia

Fama

Media

Sui cognitio

Passionum suarum regimen

morum rectitudo Virtus Laus

Vitium Vituperium

Ingeniorum eegnitio observatio

Consiliorum Indagatio penetratio

Animorum Gubernatio

Rhetorica

Logica

Oeconomica

Mercatura

Artis exercitium

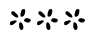




\section{'Adversaria' (MS Locke f. 15, pp. 119-120, crossed out)}

[p. 119]

Cognoscendorū $[\mathrm{m}] \quad$ Philosophica

\begin{abstract}
i.e. Quicquid conducere possit ad notitiam enti eorumque causarum proprietatum effectium et consequentiarum ut sc: eorum habeamus veras, claras et destinctas Ideas. Quicquid hujusmodi occurrit distribuendum in capita secundum varias rerū $[\mathrm{m}]$
\end{abstract}

Species

\begin{tabular}{|c|c|c|c|}
\hline Reminiscendorū $[\mathrm{m}]$ & Historica civilia & $\begin{array}{r}\text { In quibus Opiniones et } \\
1 . \text { Traditiones de }\end{array}$ & $\begin{array}{l}\text { Deo } \\
\text { Creatione } \\
\text { Revelatione } \\
\text { Prophetia } \\
\text { Miraculis } \\
\text { Spiritibus } \\
\text { Anima } \\
\text { Paradisus } \\
\text { Gehenna }\end{array}$ \\
\hline
\end{tabular}

2. Et de ijs quae supponentur Instituta lege divina sc:

Officiis religiosis

peccatis

Indifferentibus

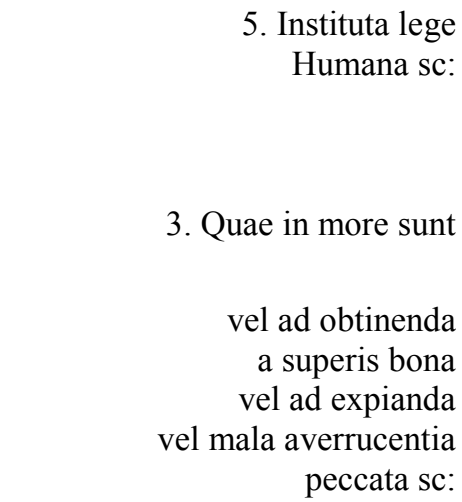

Officia civila

Crimina

Licitia

Decora

Indecora

Virtutes. consuetudines.

Vitia. Indulgentia.

memorabilia

Petitoria

Expiatoria

Sacerdotes

Supernaturalia quae faciunt sc:

Praedictiones

Magica

$\ddot{*} \because \because \because *$ 


\section{'Adversaria' (MS Locke c. 28, f.50 ${ }^{\mathrm{r}}$ )}

[f. $\left.50^{\mathrm{r}}\right]$

19 Aug. $\underline{77}$

Cognoscendorum Philosophica

Reminiscendorum Historica civilia
In Legendis Authoribus haec mihi praecipue observanda videntur

\author{
i.e. Quicquid conducere possit ad \\ notitiam entium eorumque causarum \\ proprietatum effectium et \\ consequentiarum ut sc: eorum \\ habeamus veras, claras et destinctas \\ Ideas. Quicquid hujusmodi occurrit \\ distribuendum in Capita \\ Secundum varias rerum
}

In quibus Opiniones et Traditiones de

Deo

Creatione

Revelatione

Prophesia

Miraculis

Spiritibus

Anima

Paradisus

Gehenna

Et de ijs quae supponentur instituta lege divina sc:

Officiis religiosis

peccatis

Indifferentibus

Instituta lege humana vel usu sc:

Officia civila

Crimina

Licitia

Decora

Indecora

Quae faciunt vel ad obtinenda a superis bona [>vel mala averrucentia]

Virtutes

Vitia

Indola consuetudines

vel ad expianda peccata

$$
\mathrm{Sc}
$$

Supernaturalia [>quae faciunt] sc:

Praedictiones

Magica
Memorabilia

Petitoria

Expiatoria

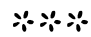




\section{Scheme 2}

'Adversaria' (MS Locke f. 2, pp. 247-52)

[p. 249]

...The first then I call

The second I call

Adversaria Philosophica w[hi]ch must be divided into the severall species of things as they come in ones way

Adversaria Theologia comprehending

1. The Opiniones or traditions are to be found amongst men concerning
God
Creation
Revelation
Prophecies
Miracles

2. Their rules or Institutes concerning things that are Dutys sins or Indifferent in matters of Religion

[p. 250]

Or things that are [Necessary] commanded Forbiden or permitted by their Municipall laws in order to Civil Society which I call

Instituta w[hi]ch contein

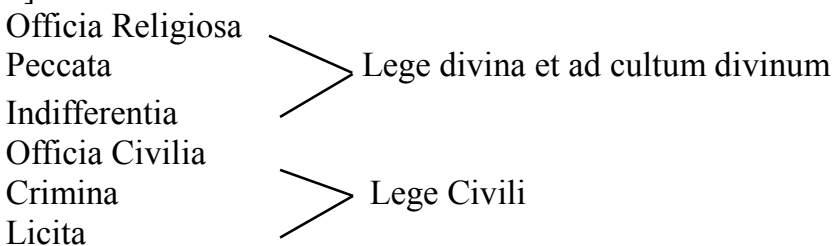

They ways they use to obteine blessings from the divinity or Attone for their sins which I call
[Intere]
Petitoria
Expiatoria

And last of all any Supernaturall things that [they might practice] are to be observed amongst them as any magicall arts or reall praedictions.

The third I call Adversaria Immitanda That is what soever wise practices are to be found either for governing [p. 251] of pollicies or a mans private self...

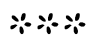

\section{'Adversaria' (MS Locke f. 15, pp.122-23)}

[p. 122]
Cognoscendorum

sc: Quicquid conducere possit ad notitiam entium eorumque causarum proprietatum effectium et consequentiarum, ut sc: eorum habeamus veras, claras et destinctas ideas. quicquid hujusmodi occurrit distribuendum in Capita secundum varias rerum $\longrightarrow$ Species

Ethica

Physica 


\begin{tabular}{|c|c|c|}
\hline \multirow[t]{7}{*}{ Reminiscendorum } & $\begin{array}{r}\text { In quibus Opiniones et } \\
\text { Traditiones de }\end{array}$ & $\begin{array}{l}\text { Deo } \\
\text { Creatione } \\
\text { Revelatione } \\
\text { Prophetia } \\
\text { Miraculis } \\
\text { Spiritibus } \\
\text { Anima } \\
\text { Paradisus } \\
\text { Gehenna }\end{array}$ \\
\hline & $\begin{array}{r}\text { Et de iis quae supponentur instituta } \\
\text { lege divina sc: }\end{array}$ & $\begin{array}{l}\text { Officiis religiosis } \\
\text { peccatis } \\
\text { Indifferentibus }\end{array}$ \\
\hline & $\begin{array}{r}\text { Quae in usu habent vel ad obtinenda } \\
\text { a superis bona vel mala vel mala } \\
\text { averrucentia et peccata expianda }\end{array}$ & $\begin{array}{l}\text { Petitoria } \\
\text { Expiatoria }\end{array}$ \\
\hline & Supernaturalia & $\begin{array}{l}\text { Sacerdotes } \\
\text { Praedictiones } \\
\text { Magica }\end{array}$ \\
\hline & $\begin{array}{r}\text { Instituta lege humana } \\
\text { vel usu sc: }\end{array}$ & $\begin{array}{l}\text { Officia civila } \\
\text { Crimina } \\
\text { Licitia } \\
\text { Decora } \\
\text { Indecora }\end{array}$ \\
\hline & $\begin{array}{r}\text { Quae sunt re vera variorum } \\
\text { populorum }\end{array}$ & $\begin{array}{l}\text { Virtutes } \\
\text { Vitia } \\
\text { Indoles } \\
\text { Consuetudines }\end{array}$ \\
\hline & Particularia & memorabilia \\
\hline
\end{tabular}

\section{'Adversaria' (MS Locke c. 28, f. 51)}

[f. $51^{\mathrm{r}}$ ] $12 \operatorname{Nov} \underline{77}$

$1^{\circ}$ Cognoscendorum Philosophica i.e. Quicquid conducere possit ad notitiam entium philosophicam : Ut sc. de eorum essentiis causis effectibus veras, claras et destinctas Ideas habeamus

$1^{\circ}$ quae sunt Entis in Genere ut Metaphysica

$2^{\circ}$ specierunt entis ut Physica

[Quicquid huismodi occurri distribuendum in

eapita secundum] 
$3^{\circ}$ quae pendent ex voluntate hominum ut

Ethica [varias rerum]

$2^{\circ}$ Reminiscendorum $\quad 1^{\circ}$ Historica Religiosa

\begin{tabular}{|c|c|c|}
\hline & & $\begin{array}{l}\text { Creatione } \\
\text { [>Diluvio] } \\
\text { Revelatione } \\
\text { Prophesia } \\
\text { Miraculis } \\
\text { Spiritibus } \\
\text { Anima } \\
\text { Paradisus } \\
\text { Gehenna }\end{array}$ \\
\hline & $\begin{array}{l}2^{\circ} \text { Et de iis quae supponentur } \\
\text { instituta lege divina sc: }\end{array}$ & $\begin{array}{l}\text { Officiis religiosis } \\
\text { peccatis } \\
\text { Indifferentibus }\end{array}$ \\
\hline & $\begin{array}{r}3^{\circ} \text { Quae in usu sunt ad } \\
\text { conciliandos superos vel } \\
\text { expianda peccata sc: }\end{array}$ & $\begin{array}{l}\text { Petitoria } \\
\text { Expiatora } \\
\text { Sacerdotes }\end{array}$ \\
\hline & $\begin{array}{r}4^{\circ} \text { Supernaturalia ut Oracula } \\
\text { Prodigia } \\
\text { Divinationes } \\
\text { Praesagia }\end{array}$ & Praedictiones \\
\hline & $\begin{array}{r}\text { Effectus supernaturales arte } \\
\text { humana produci }\end{array}$ & Magica \\
\hline & $1^{\circ}$ Instituta lege humana sc: & $\begin{array}{l}\text { Officia civila } \\
\text { Crimina } \\
\text { Licita }\end{array}$ \\
\hline & $2^{\circ}$ Stabilita usu sc: & $\begin{array}{l}\text { Decora } \\
\text { Indecora } \\
\text { Consuetudines }\end{array}$ \\
\hline & $3^{\circ}$ Populorum & $\begin{array}{l}\text { Indoles } \\
\text { Vitia }\end{array}$ \\
\hline & $4^{\circ}$ Memorabilia & $\begin{array}{l}\text { Natura } \\
\text { Artis } \\
\text { Facta } \\
\text { Dicta }\end{array}$ \\
\hline
\end{tabular}




\title{
'Adversaria' (MS Locke c. 42, p.22)
}

[p. 22]

Religio Officium Peccatum Lege Civile Mandatum Crimen Virtus sive in Honestum In conversatione Decorum Indifferens

Licitum

Opinione Turpe

Indifferens

In persona Formosum In nascita et in Venustas

Deforma
Invenusim
Acquirenda
Commutanda
Redenda

\section{'Adversaria 1661' (back endpaper)}

\section{Theologia}

\author{
Deus O[ptimus] M[aximus] \\ Heroes, sive hominum apotheosis sive dij adscititij \\ Idola, sive dij factitij \\ Naturalia sive dij inventi \\ Spiritus \\ Boni \\ Mali \\ Spectra \\ Revelatio \\ Prophetia \\ Oracula \\ Insomnia \\ Visiones \\ Enthusiasmus \\ Magia \\ Incantatio \\ Obsessio \\ Exorcismus \\ Divinatio \\ Miracula \\ Praestigia
Anima separata
Immortalis
Praemium
Poena
Coelum
Gehenna
Transmigratio
Psychopannuchia

Dicta

Facta

Responsa 


\section{Mundus \\ Aeternus \\ Creatus \\ Cultus \\ Tempus \\ Locus \\ Preces \\ Sacrificia \\ Oblationes \\ Ceremonia \\ Ritus \\ Sacerdotes}

\section{Ethica}

Virtutes. Vitia. Indifferentia. Licita.

$\because ே \div \div \div 0$ 


\section{Scheme 3}

'Adversaria' (MS Locke c. 28, ff. 157-58)

\author{
[f. $\left.157^{\mathrm{r}}\right] \quad$ Metaphysica \\ Ens \\ Affectiones transcendendales et attributa \\ Essentia \\ Existentia \\ Unitas \\ Identitas \\ Duratio \\ Relatio
}

\section{Theologia}

\section{Deus Op[timus] Max[imus]}

Dij ascititij i.e. Homines in Deos relati sive Heroes

Dij factitij sive Idola

Dij inventi sive res na[tur]ales pro dijs habitae

\section{Spiritus}

Angeli

Daemones

Spectra

Lemures

Obsessio

\section{Mundus \\ Aeternus \\ Creatus \\ Revelatio \\ Prophesia \\ Vaticinia \\ Insomnia \\ Visiones \\ Enthusiasmus \\ Miracula}

Hactenus quid credendum sequitur q[ui]d agendum

\section{Cultus}

Tempus Festi

Locus Templa

Ritus et Ceremonia

Petitoria

Expiatoria et averruncantia

Eucharista

Sacrificia

Oblationes

Confessio Jejunium

Precatio

[f.157v] Gratiarum actio

Laudes

Sacredotes

Ministri

Moralia

Officium Religiosum

Peccatum

Indifferens 


\title{
Scheme 4
}

Untitled (MS Locke c. 28, ff. 155-56)

[f. $\left.155^{\mathrm{r}}\right]$

\section{Physica}

\author{
$1^{\mathrm{o}}$ Theologia

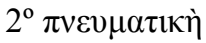

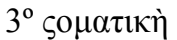

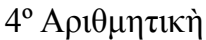 \\ $5^{\circ} \gamma \varepsilon 0 \mu \varepsilon \tau \rho 1 \alpha$
}

[f. $156^{\mathrm{r}}$ ]

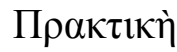

$1^{\circ}$ Ethica, vitae ratio secundum leges a deo omnibus hominibus datas Ejus finis Beatitudo

$2^{\circ}$ Politica, Sociandorum gubernandorumque hominum scientia ejus finis pax et faelicitas societatis

$3^{\circ}$ Prudentia civilis. Ejus finis est ut alios homines sibi habeat amicos benignos utiles comes. Ad hanc necessaria est hominum cognitio i.e. Temperamenti, Indolis, Consilij

$4^{\circ}$ Prudentia monastia. Ejus finis Tranquillitas Media cognitio sui ipsi [FacultatumDe] i.e. Facultatum, Defectum, [Inclination] Inclinationum, Passionum \& horum remedia

$5^{\circ}$ Oeconomia cujus finis opes. Media artis qua duplices, primo quae consistunt in aliquo solum opere humano, ut scribendi, pingendi, tornandi, nendi, textoria. Secundo quae [f. $\left.156^{\mathrm{v}}\right]$ consistunt in opere rerum ipsarum, sed debito modo junctarum ut Ars fructoria, chymica [Hortmant Quibus addi possit artium [ex his] altera species ex his duabus prioribus compositarum Ut [Agrieola et Hortman] Agricultura Horticultura Fabrilis ferraria

$$
\because 0 \div-\div
$$

